Demand-side Management Strategies and the Residential Sector: Lessons from International Experience Aoife Brophy Haney, Tooraj Jamasb, Laura M. Platchkov, Michael G. Pollitt

November 2010

CWPE 1060 \& EPRG 1034 


\title{
Demand-side Management Strategies and the Residential Sector: Lessons from International Experience
}

\author{
EPRG Working Paper 1034
}

Cambridge Working Paper in Economics 1060

\section{Aoife Brophy Haney, Tooraj Jamasb, Laura M. Platchkov, Michael G. Pollitt}

Abstract

This paper explores demand side management (DSM) strategies, including both demand response and energy efficiency policies. The aim is to uncover what features might strengthen DSM effectiveness. We first look at key features of residential energy demand and the limits to energy indicators. We then turn to historical energy intensity trends in the sector which uncover its large untapped potential. A range of barriers to energy efficiency accounting for this gap are surveyed as well as a number of potential policy responses. This reveals the necessity of a portfolio approach with bundled strategies that simultaneously impact different parts of the market, enhance the strengths of individual measures while compensating for their weaknesses through the use of complementary policies. Evidence from the international experience, in Denmark, Germany, Japan, and US is reviewed. This helps us to contrast and shed some light on the UK experience. We conclude with an emphasis on the need for a holistic underpinning approach and the indentification of a number of attributes that reinforce DSM strategies.

Keywords

Contact

Publication

Financial Support electricity, heat, energy policies, demand-side management, energy efficiency, residential sector, portfolio approach
Ip361@cam.ac.uk

November 2010

EPSRC Flexnet
$\mathrm{E} \cdot \mathrm{S} \cdot \mathrm{R} \cdot \mathrm{C}$

ECONOMIC

\& SOCIAL RESEARCH COUNCIL 


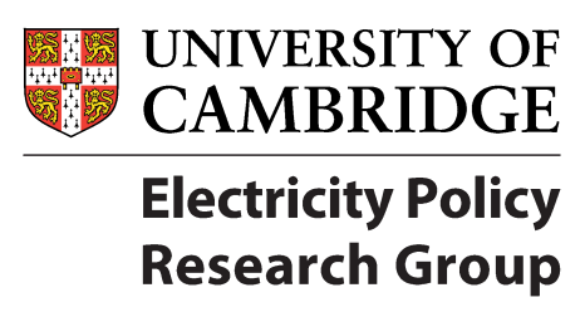

JEL Classification Q41, Q48, D10 


\title{
Demand-side Management Strategies and the Residential Sector: Lessons from International Experience $^{1}$
}

\author{
Aoife Brophy Haney \\ ESRC Electricity Policy Research Group and \\ Judge Business School, University of Cambridge \\ Tooraj Jamasb ${ }^{2}$ \\ ESRC Electricity Policy Research Group and \\ Faculty of Economics, University of Cambridge \\ Laura M. Platchkov ${ }^{3}$ \\ ESRC Electricity Policy Research Group and \\ Faculty of Economics, University of Cambridge \\ Michael G. Pollitt \\ ESRC Electricity Policy Research Group and \\ Judge Business School, University of Cambridge
}

\footnotetext{
${ }^{1}$ This paper is a version of a chapter in The Future of Electricity Demand: Customers, Citizens and Loads edited by Tooraj Jamasb and Michael G. Pollitt (to be published by Cambridge University Press). The work was supported by ESRC Electricity Research Group and the EPSRC Flexnet project. The authors would like to acknowledge the comments from two anonymous referees.

${ }^{2}$ Now at Heriot-Watt University.

${ }^{3}$ Corresponding author: Laura Platchkov, Faculty of Economics, University of Cambridge, Austin Robinson Building, Sidgwick Avenue, Cambridge CB3 9DD, United Kingdom. Telephone: +44 (0)1223 335286, E-mail: lp361@cam.ac.uk.
} 


\section{Introduction}

Policies and measures targeting energy demand took off over the last three decades in response firstly to the oil shocks of the 1970s. Since then, concerns about the sensitivity of the economies to energy prices, oil dependency and more recently climate change, contributed to the development of energy efficiency (EE) policies. ${ }^{4}$ Demand-related policies that aim to influence quantities or patterns of energy use have traditionally been referred to as demand-side management (DSM) programmes. They include both energy efficiency policies and demand response (DR). 5 Energy efficiency improvements can bring many benefits in terms of reduced energy infrastructure investments, decrease in electricity prices, increased energy security, improved environmental quality, and others ancillary benefits. ${ }^{6}$ Scientists estimate that by 2050 , we need to have reduced our greenhouse gas emissions (GHG) by $50 \%$ to avoid the worst-case scenarios of climate change. In such context, the building sector appears as the "cornerstone of every national climate change strategy", as it is responsible for up to $30 \%$ of global annual GHG emissions, and $40 \%$ of all energy consumption (UNEP, 2009). Furthermore, there is wide evidence of the costeffectiveness of energy efficiency measures as compared to renewable programmes (IEA, 2006). In parallel, load growth; increased intermittency due to renewable generation; and, in the UK in particular, the renewal and reconfiguration of the electricity network poses challenges to the electricity sector never seen before. These challenges increasingly lead to the recognition of the importance of active consumers participation in load shifting, and hence interest in influencing quantities or patterns of energy demand.

There is now substantial experience particularly among OECD countries in using policy instruments to improve the overall efficiency with which energy is used. Several recent studies have assessed these experiences. For example, Geller et al. (2006) review energy intensity trends in the OECD from 1973 to 2003. They focus on the specific policies adopted by Japan, the US, and a selection of European countries to improve energy use per unit of GDP across sectors. The World Energy Council (WEC) has conducted a review of energy efficiency policies using a survey of 70 countries, including examples of the most effective types of policy measures (WEC, 2008). Similarly, the United National Environment Programme Sustainable Buildings \& Climate Initiative (UNEP-SBCI) published several reports assessing the implemented policies in various countries. A number of International Energy Agency (IEA) publications have also looked at energy use trends (IEA, 2007; IEA, 2008); reviewed the implementation of energy efficiencies policies in general (IEA, 2009b); and in the residential sector in particular (IEA, 2008).

\footnotetext{
${ }^{4} \mathrm{By} \mathrm{EE}$ we refer to the amount of energy needed for a given service (heating, lighting, etc.) or level of activity. See section 2 for a discussion of EE indicators.

${ }^{5}$ Pricing is at the heart of DR, which aims at increasing the elasticity of demand, including the cost-reflectivity of prices.

${ }^{6}$ For instance, reduced air pollution, increased health quality and energy security are amongst important co-benefits.
} 
Some areas of general consensus emerge from these cross-country studies. First, the socalled "energy efficiency gap"7 of the building sector is particularly highlighted, together with the huge potential for cost-effective or "negative costs" measures. Second, as we will discuss in this chapter, some features of the residential sector hinder optimal energy choices. These studies also show that there is still little understanding of the impacts of a specific measure and, more crucially, of the reasons behind those impacts (UNEP, 2009), as shown by the differences in experiences from one country to the other. Last but not least, packages of integrated, complementary policies are much more effective in addressing barriers to energy efficiency than single measures. Several countries are mentioned as having successfully achieved integrated policymaking: Germany; Denmark; Japan; the US, particularly states such as California; and Australia (de T'Serclaes, 2007; Uihlein and Eder, 2009). Even if the relative "success" of certain countries needs to be matched to the specific original level of discretionary load, a closer examination of their strategies can offer useful lessons. In addition to policy packages, engaging the private sector is acknowledged as being central to ensuring long-lasting impact; and the importance of institutional framework and national context are emphasised in relation to policy stability and sustainability.

In this paper we focus on DSM policies - i.e. including both energy efficiency policies and demand response - targeting residential demand for electricity and heat, i.e. households energy demand from buildings and appliances, increasingly considered by stakeholders (Torriti et al., 2010; see also Silva et al., 2011 and Torriti et al., 2011). The objective is to understand why an integrated policy package is more likely to be successful than single policies. In section 2 we discuss some limits to aggregated energy indicators and to crosscountry comparisons. This reveals the importance of the residential sector in energy demand. We then review past and recent energy demand trends in this sector, and uncover large untapped potential. This is due to specific barriers to energy demand reduction, discussed in section 3. In section 4, we present examples of policy responses to overcome those barriers. This leads us to discuss, in section 5, policy packages and the importance of comprehensiveness in DSM demonstrated by several case studies, and draw some lessons for the UK from the international experience.

\section{The residential energy demand: key features}

\subsection{Energy efficiency measures and the residential sector}

Greater energy efficiency is an essential part of overcoming the challenges facing the energy sector and considerable improvements are needed compared to recent trends (IEA, 2008). Here, energy efficiency improvement is defined as a reduction in the energy used for a given service (heating, lighting, etc.) or level of activity (WEC, 2008), typically without affecting the level of end-use service. Comparing energy efficiency performance across countries is difficult.

\footnotetext{
${ }^{7}$ A simple definition of the energy efficiency gap reads as the difference between current or expected future energy use and the optimal current or future energy use (Jaffe and Stavins, 1994).
} 
First and foremost, energy indicators at the scale of the whole economy, such as the ratio of total final consumption to GDP are often used as proxy for energy efficiency and to assess how successful countries have been at reducing demand. Such a high level of aggregation conceals specific trends and makes the measure very rough. Nowadays, a bottom-up approach is becoming increasingly popular. Such approach distinguishes between the structural components of energy demand and the intensity with which energy is used (Unander et al., 2004; Ang, 2006; Taylor et al., In Press).

As an example, the structural components of residential energy demand include floor area per capita; persons per household; and appliance ownership per capita. Each of these drives the demand for energy services which in turn drives absolute, as well as per capita, energy use. Those components are dependent on demographics, income distribution, prices and climate and cannot all necessarily be influenced by energy efficiency measures. Energy intensity, on the other hand, refers to the energy used in producing a given level of output or activity. It is measured by the quantity of energy required to perform a particular activity (service) expressed as energy per unit of output or activity measure of service (EERE, 2010). In the residential sector, energy intensity can be measured per household or capita. Increases in energy efficiency help to reduce energy intensity; and changes in other factors can sustain or counteract improved efficiencies, e.g. changes in usage patterns (Unander et al., 2004). In UK households for instance, there has been a reduction of $9 \%$ in energy consumption per household between 1990 and 2009, but only 1\% if measured per capita (DECC, 2010). This is explained by structural changes - e.g. increase in households' number - as well as increase in the number of appliances, both of which have gradually offset the improvement in energy efficiency in insulation and heating.

Second, turning to the performance in terms of policies, ex-post evaluation studies are difficult to find, often not publicly available or not translated, if not non-existent (Koeppel and Urge-Vorsatz, 2007). When available, challenges arise due to the lack of data and differing evaluation methods ${ }^{8}$ or measurement and verification (M\&V) protocols (Ramesohl and Dudda, 2001; Gillingham et al., 2006; IEA, 2008). It is also difficult to agree on the quantification of ancillary benefits (IEA, 2008). Gillingham et al. (2006) review exante and ex-post studies assessing the cost-effectiveness of different policies implemented in the US. Regarding appliances standards for instance, the studies display wide range of assessments.

A third important caveat to bear in mind is due to country-specific factors when analysing demand-side strategies. Policies are implemented within complex political, economical, and cultural environments. They interact with other policies from which synergies can trigger or weaken their effect (Koeppel and Urge-Vorsatz, 2007).

\footnotetext{
${ }^{8}$ For instance, differences occur in the inclusion or not of transaction and administrative costs or -when knowndiffering baselines.
} 
Looking at disaggregated energy indicators reveals the importance of the residential sector. Energy demand from residential buildings represented $40 \%$ of world's total primary consumption (IEA, 2008). Projections suggest that following the global economic downturn, demand for electricity from buildings is expected to grow at 3.1\% between 2007 and 2020 (McKinsey, 2009). In the UK, households account for around 30\% of the final energy consumption with an increase of 5.8\% between 1990 and 2006; and only a recent decline of 6.5\% from 2000 to 2007 (BRE, 2008; Utley and Shorrock, 2008; MURE, 2009). Hence, the residential sector should be a major component of a demand side energy strategy. Furthermore, it offers cost-effective opportunities with the lowest investment needs but its potential has traditionally been largely intractable due to a range of barriers discussed hereafter (McKinsey, 2008; IEA, 2009c).

\subsection{Historical residential energy trends and the potential for demand reduction}

Energy efficiency improvements for households in IEA countries have been significantly lower since 1990 (Taylor et al., In Press) than during the period starting in 1973, when responding to the oil shocks was a driving force behind energy policy. Besides, total final consumption in 15 countries of the IEA increased between 1990 and 2004 due mainly to a rapid rise in electricity demand from appliances. As a result, there has been a $15 \%$ increase in residential $\mathrm{CO}_{2}$ emissions over the same period (IEA, 2007). In the UK, factors pushing energy demand upwards include the increase in the demand for space heating $\left(6^{\circ} \mathrm{C}\right.$ since 1970 ), which today accounts for $60 \%$ of total residential energy demand; in the number of households (30\%), and a poor quality of buildings (Boardman, 2005; Clarke et al., 2008; MURE, 2008; Utley and Shorrock, 2008).

Taylor et al. (In Press) provide an overview of household energy use per capita for 19 IEA countries for 1990 and 2005, space heating being by far the largest end-use category, accounting for $53 \%$ of final household energy use in 2005 . The shares by different end-use categories vary a little among countries, but the variation is the greatest as regards water heating. What is also interesting is to examine the decomposition over time. Figure 1 shows that decomposition for the UK from 1970 to 2008. As we can see, household energy use from lighting and appliances is the category which has most increased over time. 
Figure 1 UK energy consumption by end use, 1970-2008

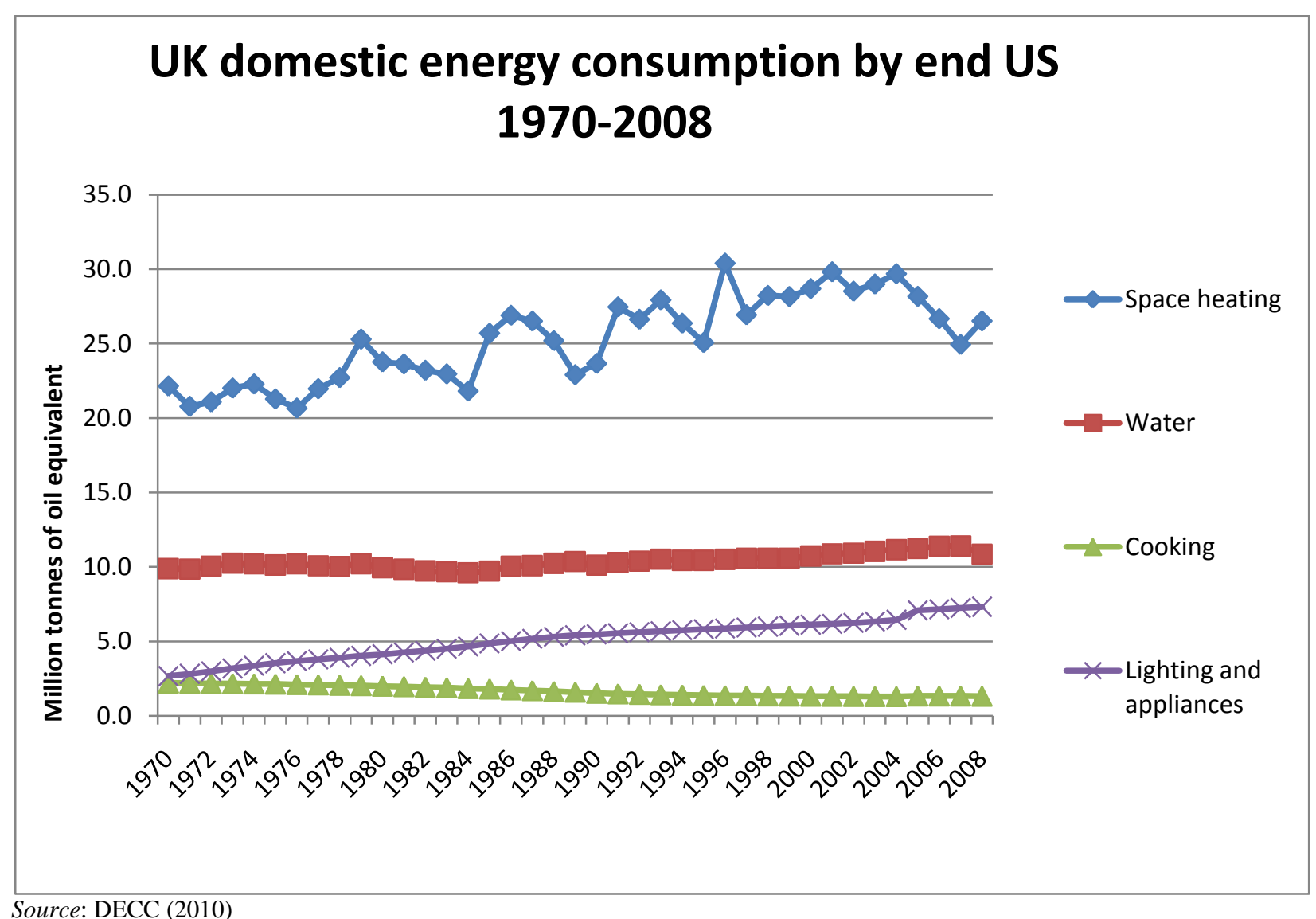

Taylor et al. (In Press) further show that the differences among countries in per capita household energy use are much less pronounced when climate is controlled for, i.e. when values are normalised based on heating degree days. Hence, further decomposing the effects of structure and end-use intensities gives a much more accurate picture of how countries compare to each other. Taking space heating as an example, Figure 2 decomposes the changes in heating per capita in the IEA 15. For most countries, the intensity effect, i.e. a reduction in energy intensity mainly from improved insulation, has dominated and has in general led to reductions in space heating per capita. Structural effects have been dominant, however, in the UK where larger dwellings and fewer occupants have led to an increase in per capita space heating. 
Figure 2 Decomposition of changes in heating per capita, 1990 - 2005

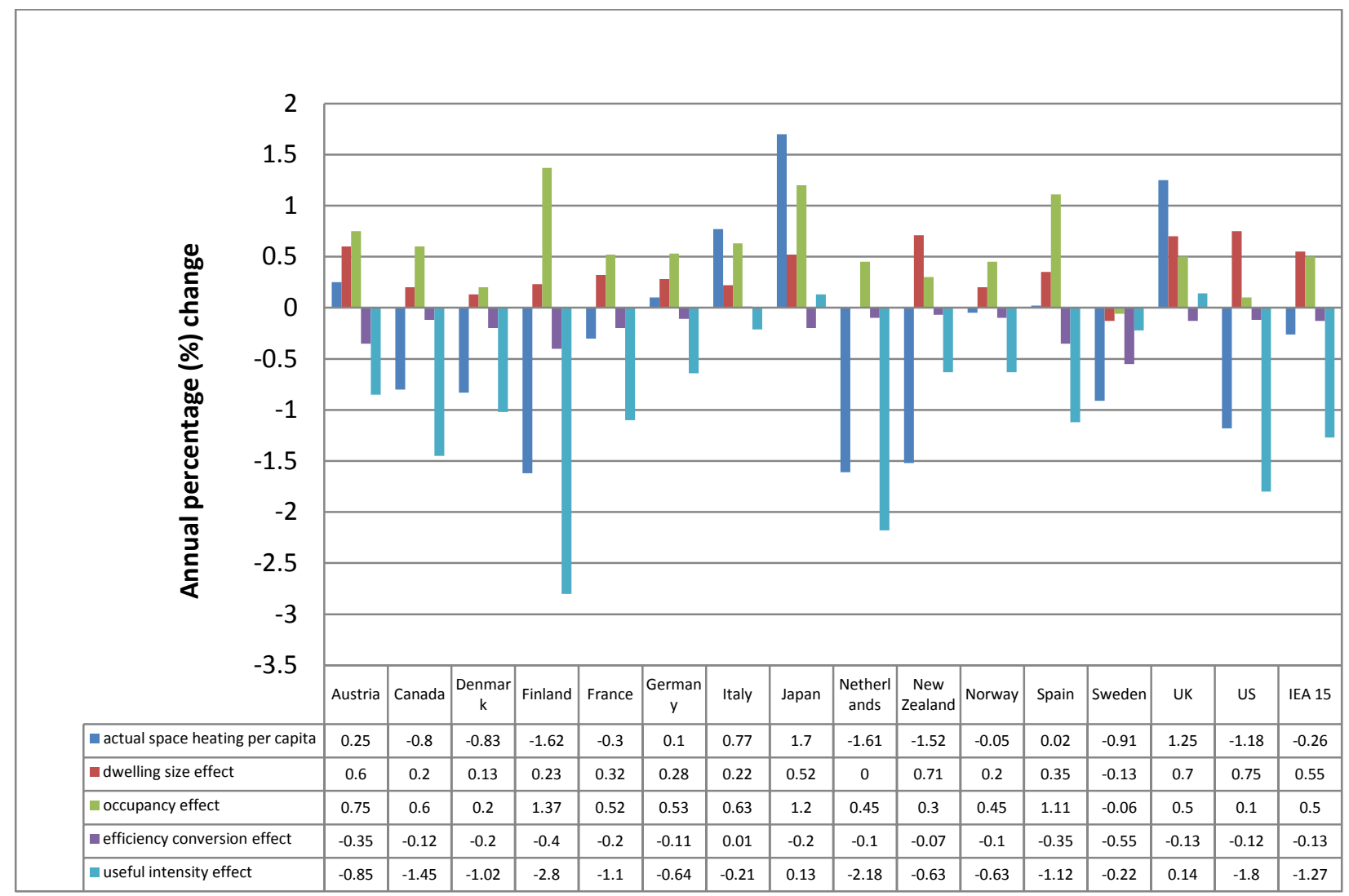

Source: IEA (2007)

shows the changes in space heating intensity ${ }^{9}$ for the same period for 19 countries in the IEA. The most significant reductions in intensity have been in the Netherlands and South Korea. Countries with milder winter climates dominate the left-hand-side of the graph, i.e. those with higher space heating intensities. This is probably due to lower levels of insulation in older buildings (Taylor et al., In Press). Building codes and minimum energy performance standards (MEPS) have a central role to play (and indeed have already been central) in further increasing space heating efficiency. Even with this type of end-use specific indicator, however, it is not possible to identify the exact impact of such policies (IEA, 2008).

\footnotetext{
9 Space heating intensity is defined as the "useful energy"-i.e. final energy minus loss estimated for boilers- for space heating per square metre. To allow for comparisons across countries with different climates, the space heating intensity is divided by each country's yearly number of heating degree-days (Taylor et al., In Press).
} 
Figure 3 Useful space heating intensity

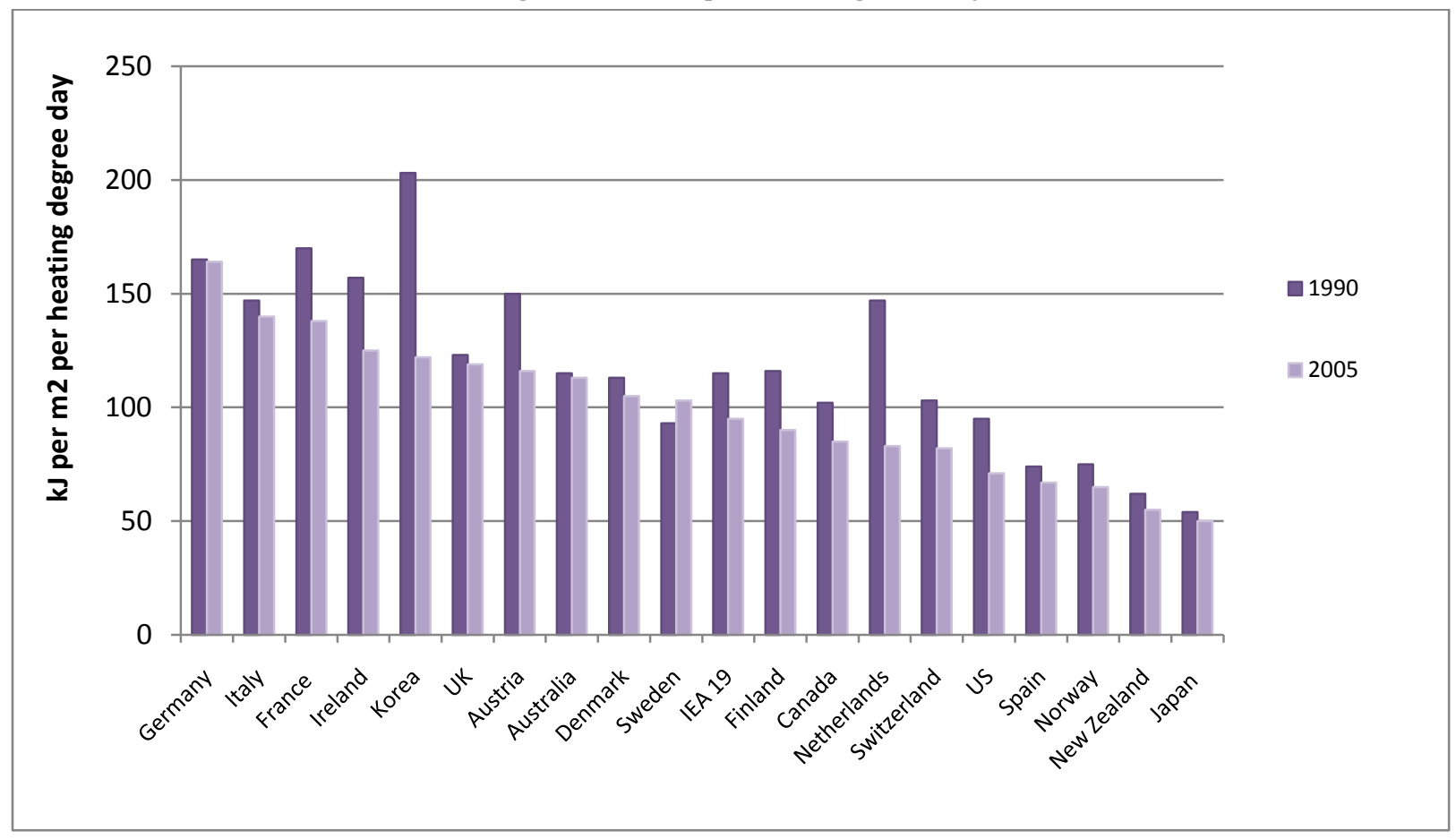

Source: Taylor et al., (In Press)

\section{Barriers to energy efficiency in the residential sector}

The trends in energy use discussed above reflect a number of barriers to energy efficiency and demand response ${ }^{10}$ in the residential sector. There is a substantial literature on the barriers to $\mathrm{EE}$ and on the importance of appropriate policy responses in overcoming these. Several authors have emphasised the distinction between market failures, e.g. stemming from a flaw in the operation of the market, and market barriers, e.g. stemming from obstacles other than market driven (Brown, 2001). Intervening to correct market failures improves both energy efficiency and economic efficiency, whereas overcoming a market barrier improves energy efficiency but at a cost to consumers (Jaffe et al., 1999; Brown, 2001). Others have sought to supplement the market failure approach with insights from areas such as transaction costs and behavioural economics. Sorrell (2004) offers a comprehensive overview and advocates a broader understanding of barriers to energy efficiency which includes organisational and behavioural barriers as well a more realistic view of the consumer decision-making process; and suggests that the importance of overcoming these additional barriers is often underestimated.

Table 1 collates the main barriers to energy efficiency affecting the residential sector which results in suboptimal investments, and possible generic remedies based on this literature ${ }^{11}$.

\footnotetext{
${ }^{10}$ With barriers to EE and to DR, we are referring to characteristics or circumstances that prevent consumer behaviour from being economically as well as energy efficient (Sorrell, 2004).

${ }^{11}$ Due to space constraints, we only briefly mention those barriers and rather focus on policy responses.
} 
Even a cursory glance shows how complex and interrelated many of the barriers and responses are. Market barriers, in particular access to capital due to high up-fronts, are among the most important barriers to energy efficiency in the residential sector. By contrast, behavioural barriers are perhaps amongst the most difficult to address as changing behaviour and lifestyle is very difficult.

Many policies have been implemented to varying degrees internationally. At the same time, considerable potential remains for both energy efficiency and demand response in the residential sector which suggests that overcoming many of the barriers in an effective way has yet to be achieved. Barriers to demand response are closely linked to the market failure barriers, particularly imperfect information and split incentives. Indeed, asymmetries of information and inelasticity of demand, mainly due to a lack of cost-reflective pricing, are the two main obstacles to a more responsive demand-side. Demand response has been largely neglected in policymaking until very recently. Policy support is now growing, however, in the European Union (EU) and within individual member states as well as in the US (Torriti et al., 2010).

Table 1 Barriers to Energy Efficiency in the building sector

\begin{tabular}{|c|c|c|c|c|}
\hline Category & Barriers & Description & Examples/Possible causes & $\begin{array}{l}\text { Generic } \\
\text { remedy }\end{array}$ \\
\hline \multirow[t]{3}{*}{$\begin{array}{l}\text { Market } \\
\text { failure }\end{array}$} & $\begin{array}{l}\text { Imperfect } \\
\text { information }\end{array}$ & $\begin{array}{l}\text { When information is } \\
\text { expensive, unreliable and/or } \\
\text { difficult to obtain }\end{array}$ & $\begin{array}{l}\text { Lack of or incomplete real pricing } \\
\text { and/or consumption information }\end{array}$ & $\begin{array}{l}\text { Increase and/or } \\
\text { improve quantity \& } \\
\text { quality of information }\end{array}$ \\
\hline & $\begin{array}{l}\text { Negative } \\
\text { externalities/ } \\
\text { absence of } \\
\text { markets for } \\
\text { EE }\end{array}$ & $\begin{array}{l}\text { When there is a lack of } \\
\text { effective pricing (e.g. negative } \\
\text { impacts, social costs or } \\
\text { benefits are unpriced) or } \\
\text { when EE is a by- } \\
\text { product/attribute for which } \\
\text { the consumer has no choice }\end{array}$ & $\begin{array}{l}\text { Costs of } \mathrm{CO}_{2} \text { emissions not included in } \\
\text { fuel prices; retail price of electricity does } \\
\text { not reflect real-time costs of production; } \\
\text { failure to capture the benefits of R\&D } \\
\text { investments by private entities; absence } \\
\text { of choice in EE levels }\end{array}$ & $\begin{array}{l}\text { "Internalization" of } \\
\text { unaccounted costs }\end{array}$ \\
\hline & $\begin{array}{l}\text { Split } \\
\text { incentives }\end{array}$ & $\begin{array}{l}\text { When an agent has the } \\
\text { authority to act on behalf of a } \\
\text { consumer, but does not reflect } \\
\text { consumers' best interests }\end{array}$ & $\begin{array}{l}\text { Principal-agent problem (e.g. landlord- } \\
\text { tenant split or utilities versus clients, } \\
\text { fees structures for engineers and } \\
\text { architects); involvement of } \\
\text { intermediaries in the purchase of energy } \\
\text { technologies }\end{array}$ & Re-align incentives \\
\hline \multirow{2}{*}{$\begin{array}{l}\text { Market } \\
\text { barrier }\end{array}$} & Risk & $\begin{array}{l}\text { When risks (real or perceived) } \\
\text { are not captured directly in } \\
\text { financial flows }\end{array}$ & $\begin{array}{l}\text { Length of the payback period; } 13 \\
\text { uncertainty about future energy } \\
\text { prices/regulations }\end{array}$ & $\begin{array}{l}\text { Reduce } \\
\text { real/perceived } \\
\text { uncertainty and risk }\end{array}$ \\
\hline & $\begin{array}{l}\text { Transaction } \\
\text { costs - Hidden }\end{array}$ & $\begin{array}{l}\text { When costs (real or perceived) } \\
\text { are not captured directly in }\end{array}$ & $\begin{array}{l}\text { Costs involved in finding appropriate } \\
\text { information/equipment, costs due to }\end{array}$ & $\begin{array}{l}\text { Reduce } \\
\text { real/perceived }\end{array}$ \\
\hline
\end{tabular}

\footnotetext{
${ }^{12}$ Energy producers and consumers may also have varying access to financial capital and at different interest rates, with low income households usually having virtually no ability to borrow funds.

${ }^{13}$ Short payback required by consumers as a response to risk of investing/discount rate is higher than interest rates to borrow money.
} 


\begin{tabular}{|c|c|c|c|c|}
\hline & costs & financial flows & $\begin{array}{l}\text { potential incompatibilities/mistrust on } \\
\text { appliance or building energy } \\
\text { performance }\end{array}$ & uncertainty and risk \\
\hline \multirow[t]{2}{*}{$\begin{array}{l}\text { Behavioural } \\
\text { economics }\end{array}$} & $\begin{array}{l}\text { Bounded } \\
\text { rationality }\end{array}$ & $\begin{array}{l}\text { When individuals do not make } \\
\text { decisions in optimal way, and } \\
\text { hence neglect EE } \\
\text { opportunities }\end{array}$ & $\begin{array}{l}\text { Constraints on time, resources and } \\
\text { ability to process information, even } \\
\text { when good information is available }\end{array}$ & $\begin{array}{l}\text { Raise awareness and } \\
\text { available information }\end{array}$ \\
\hline & $\begin{array}{l}\text { Low } \\
\text { priority/inter } \\
\text { est of energy } \\
\text { issues }\end{array}$ & $\begin{array}{l}\text { When EE opportunities are } \\
\text { missed as a consequence of } \\
\text { lack of awareness and interest }\end{array}$ & $\begin{array}{l}\text { Energy costs are a small percentage of } \\
\text { total household costs; energy subsidies } \\
\text { in developing countries }{ }^{14}\end{array}$ & $\begin{array}{l}\text { Raise awareness and } \\
\text { available information }\end{array}$ \\
\hline Others & $\begin{array}{l}\text { Political and } \\
\text { structural } \\
\text { barriers }\end{array}$ & $\begin{array}{l}\text { When structural } \\
\text { characteristics of the political, } \\
\text { economic, energy system } \\
\text { make EE investments difficult }\end{array}$ & $\begin{array}{l}\text { Differences in degree of liberalisation of } \\
\text { the electricity market (Blumstein et al., } \\
\text { 2005); differences in economic level } \\
\text { across regions; lack of technical skills, } \\
\text { detailed guidelines, tools and experts; } \\
\text { inadequate energy service levels }\end{array}$ & $\begin{array}{l}\text { Enhance the } \\
\text { institutions, capacity- } \\
\text { building cooperation }\end{array}$ \\
\hline
\end{tabular}

Source: Brown (2001); (Deringer et al., 2004); Sorrell (2004); (McKinsey, 2007); IEA (2008); Grubb and Wilde (2008); UNEP (2009)

\section{Demand-side management policies}

\section{1 Overview of demand-side policies}

Barriers outlined in Table 1 above justify some form of action to overcome them. Policies should aim to encourage both energy and economic efficiency (Sorrell, 2004). Timing is particularly important for electricity, where generation prices fluctuate significantly according to the time of day. At times of peak demand, for instance, electricity production costs are significantly higher because peak-load generators must be dispatched to satisfy demand. Most residential customers are not exposed to these changes so that there is little incentive to shift consumption away from times when it is most expensive to produce. Future peak-load plant investment decisions are affected by this lack of demand response, as is the ability to match demand and supply reliably. DSM includes demand response and energy efficiency measures, such as load management, energy efficiency and electrification activities and has evolved in response to changes in industry structure and policy priorities since the oil shocks in the 1970s (CRA, 2005). DSM can be administered by utilities, state agencies, or non-profit organisations. More recently, dynamic demand-side activities such as time-of-use (TOU) or critical-peak pricing (CPP) and other forms of demand response, e.g. interruptible loads, have become central to improving market efficiency and system control (Bilton et al., 2008).

We are interested in analysing the wide range of demand-side policies implemented internationally. This includes policies that seek to reduce demand and improve overall energy efficiency as well as those that aim to improve the economic efficiency with which energy is used. Our focus is on demand-side strategies, i.e. packages ${ }^{15}$ of measures that aim to overcome barriers in a coherent and coordinated way. This type of approach lends itself well to demand-side policymaking where there is a range of barriers, several policy goals

\footnotetext{
${ }^{14}$ Such subsidies can provide disincentives for rational use of energy (Alam et al., 1998).

${ }^{15}$ Here, a package refers to programmes combining different policies.
} 
and a vast array of potential policy instruments that need to work simultaneously and in support of each other.

The literature on cross-country and cross-state analyses of policy packages identifies 18 major policies targeting the residential sector, which we classify into six general policy categories that we would expect to see in a comprehensive strategy (see Table 2). Some policies are strongly linked together and/or might overlap, however all categories are important. In our discussion, we follow the evaluation criteria proposed by the UNEP-SBCI initiative, where policies are evaluated according to their strengths, weaknesses, and effectiveness - the achievement of their goal, i.e. increase in energy efficiency and/or reduction of GHG emissions-, their cost-effectiveness where data is available 16 - and the factors triggering or hindering their success. Market transformation ${ }^{17}$ offer guarantees of success and should be one of the ultimate objective. Table 3 offers an overview of the latter, and table 4 gives some examples of costs estimates. Care should be taken when evaluating and selecting policies, given the difficulty to quantify costs and benefits, and data availability (Lee and Yik, 2004; Uihlein and Eder, 2009). Technological changes and energy prices might also alter the attractiveness of programmes (IEA, 2006). Significant double counting exists in energy savings, and disentangling the effect of single programmes is a major, if not irreducible challenge. Modelling assumptions including baseline scenarios differ across programmes' and countries' evaluations studies, rendering comparisons very difficult and baselines scenarios can be debatable. The assessment hence entails important uncertainties.

\footnotetext{
${ }^{16}$ Depending on the perspective taken, cost effectiveness estimates can include the costs for programme administrator, the individual, or the society, the latter being the preferred measure.

${ }^{17}$ Market transformation is defined as "the reduction in market barriers due to a market intervention, as evidenced by a set of market effects that lasts after the intervention has been withdrawn, reduced or changed"(Eto et al.1996, p. xii).
} 
Table 2 Major demand-side policies in the residential sector and their definition

\begin{tabular}{|c|c|c|c|}
\hline \multicolumn{2}{|l|}{ Category } & Example of policies & Definition - policies \\
\hline \multicolumn{4}{|l|}{ Framework policy } \\
\hline \multicolumn{2}{|c|}{$\begin{array}{l}\text { A general and more abstract set of } \\
\text { principles and long-term objectives that } \\
\text { guide the development of and form the } \\
\text { basis of specific policies, and that may } \\
\text { demonstrate a holistic and/or broader } \\
\text { strategic approach. }\end{array}$} & $\begin{array}{l}\text { National EE strategies and action } \\
\text { plans (NEESAP) }\end{array}$ & $\begin{array}{l}\text { Sets a national strategy and creates institutions establishing relevant laws and programmes, } \\
\text { including } M \& V^{18} \text { guidelines and methods. }\end{array}$ \\
\hline \multicolumn{4}{|c|}{ Regulatory / control measures } \\
\hline \multirow{5}{*}{$\begin{array}{l}\text { Laws and implementation } \\
\text { regulations (e.g. } \\
\text { qualitative/quantitative } \\
\text { requirements) that require certain } \\
\text { devices, practices or system design } \\
\text { to improve energy efficiency (IEA, } \\
\text { 2005) }\end{array}$} & \multirow{3}{*}{ 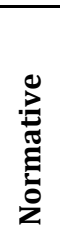 } & Appliance standards & $\begin{array}{l}\text { Define a minimum EE level for a particular product class such as refrigerators, to be fulfilled by } \\
\text { the producer (Birner et al. 2002) }\end{array}$ \\
\hline & & $\begin{array}{l}\text { Building codes for both new \& } \\
\text { existing buildings }\end{array}$ & $\begin{array}{l}\text { Address energy use of an entire buildings or building systems such as heating or air } \\
\text { conditioning (Birner and Martinot, 2002) }\end{array}$ \\
\hline & & EE obligations \& quotas & $\begin{array}{l}\text { Legal obligations for electricity and gas suppliers to achieve EE targets in households (Lees, } \\
\text { 2006) }\end{array}$ \\
\hline & \multirow{2}{*}{ 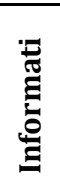 } & $\begin{array}{l}\text { Mandatory labels \& certification } \\
\text { programmes }\end{array}$ & $\begin{array}{l}\text { Mandatory provision of information to end users about the energy-using performance of } \\
\text { products such as electrical appliances and equipment, and even buildings (Crossley et al. 2000) }\end{array}$ \\
\hline & & $\begin{array}{l}\text { Mandatory audits, M\&V of energy } \\
\text { performance }\end{array}$ & $\begin{array}{l}\text { Mandatory audits, monitoring and energy management in commercial, industrial, or private } \\
\text { building, sometimes subsidized by government. }\end{array}$ \\
\hline \multicolumn{4}{|c|}{ Economic / Market based instruments } \\
\hline & \multicolumn{2}{|c|}{ Energy performance contracting (EPC) } & $\begin{array}{l}\text { A contractor, typically an Energy Service Company (ESCO), guarantees certain energy savings } \\
\text { for a location over a specified period: implements the appropriate EE improvements, and is } \\
\text { paid from the actual energy costs reductions achieved (EFA, 2002). }\end{array}$ \\
\hline \multicolumn{4}{|c|}{ Financial and incentive-based measures } \\
\hline \multirow{4}{*}{$\begin{array}{l}\text { Correct energy prices either by a } \\
\text { Pigouvian tax or by financial } \\
\text { support to address cost-related } \\
\text { barriers }\end{array}$} & \multicolumn{2}{|c|}{$\begin{array}{l}\text { Direct provision of financing } \text { (e.g. } \\
\text { preferential loans/ subsidies and } \\
\text { grants) }\end{array}$} & Financial support for the purchase of EE appliance or buildings refurbishments. \\
\hline & \multicolumn{2}{|c|}{$\begin{array}{l}\text { Fiscal measures (taxations/tax } \\
\text { exemptions/tax reductions) }\end{array}$} & $\begin{array}{l}\text { A specific tax exemption/reduction/increase at any point in the supply/demand chain used to } \\
\text { provide signals promoting investment in EE/EE behaviours to end use costumers. }\end{array}$ \\
\hline & \multicolumn{2}{|r|}{ Public benefit charges (PBC) } & $\begin{array}{l}\text { Funds raised from the operation of the electricity or energy market, which can be directed into } \\
\text { DSM/EE activities (Crossley et al. 2000) }\end{array}$ \\
\hline & \multicolumn{2}{|c|}{$\begin{array}{l}\text { Utility based programs (e.g. load } \\
\text { control programs; time-varying pricing } \\
\text { tariffs) }\end{array}$} & $\begin{array}{l}\text { Planning, implementing, and monitoring activities of EE programmes among/by utilities } \\
\text { targeting the price of electricity and/or usage pattern of end consumers. }\end{array}$ \\
\hline
\end{tabular}

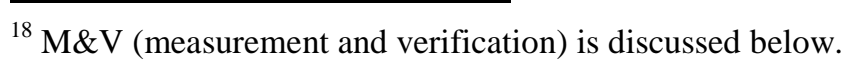




\begin{tabular}{|c|c|c|}
\hline \multicolumn{3}{|c|}{ Voluntary agreements and partnerships } \\
\hline \multirow[t]{3}{*}{$\begin{array}{l}\text { Aim at persuading consumer to } \\
\text { change their behaviour }\end{array}$} & Public-private partnerships (PPP) & $\begin{array}{l}\text { Formal partnerships between public and private actors involving specific actions targeting } \\
\text { households' energy services demand. }\end{array}$ \\
\hline & voluntary labelling \& certification & $\begin{array}{l}\text { Voluntary provision of information by producers to end users about the energy-using } \\
\text { performance of products such as electrical appliance and equipment, and even buildings } \\
\text { (Crossley et al. 2000). }\end{array}$ \\
\hline & Voluntary \& negotiated agreements & $\begin{array}{l}\text { Formal quantified agreement between a government body and a business or organisation } \\
\text { which states that the business or organisation will carry out specified actions to increase the } \\
\text { efficiency of its energy use (Crossley et al. 2000). }\end{array}$ \\
\hline \multicolumn{3}{|c|}{ Information and capacity-building } \\
\hline \multirow{4}{*}{$\begin{array}{l}\text { Aim at persuading consumer to } \\
\text { change their behaviour by } \\
\text { providing information and } \\
\text { examples of successful } \\
\text { implementation and building } \\
\text { capacity }\end{array}$} & $\begin{array}{lr}\text { Education and public } & \text { outreach } \\
\text { campaigns/awareness } & \text { raising } \\
\text { campaigns }\end{array}$ & $\begin{array}{l}\text { Policy instruments designed by government agencies with the intention to change individual } \\
\text { behaviour, attitudes, values, or knowledge (Weiss and Tschirhart, 1994). }\end{array}$ \\
\hline & Training programmes & $\begin{array}{l}\text { Policy instruments designed by government agencies to build/strengthen capacity through } \\
\text { training of energy managers, energy auditors and other energy professionals to effectively } \\
\text { manage energy with minimum external assistance. }\end{array}$ \\
\hline & $\begin{array}{lrr}\text { Utility } & \text { DSM/DR } & \text { programmes } \\
\text { (counselling } & \text { and } & \text { general } \\
\text { information } & \end{array}$ & $\begin{array}{l}\text { Planning, advisory, informational and monitoring activities of EE programmes among/by } \\
\text { utilities. }\end{array}$ \\
\hline & $\begin{array}{l}\text { Detailed billing and disclosure } \\
\text { programs (e.g. smart metering, smart } \\
\text { energy boxes }{ }^{20} \text {, dynamic pricing) }\end{array}$ & $\begin{array}{l}\text { Display detailed information related to the energy consumption to the user either on bill } \\
\text { and/or directly on appliance or meter. }\end{array}$ \\
\hline
\end{tabular}

Source: adapted from Koeppel and Urge-Vorastz (2007);(Eldridge et al., 2008); IEA (2008); WEC (2008); UNEP (2009).

\footnotetext{
${ }^{19}$ Counselling includes: individual advice and counselling, conversion of electrical heating, appraisal of electrical heating, advice of heat pump installation, and general information includes activities changing energy behaviour, education of school children, lending out of meters and low-energy bulbs, show and display rooms, articles, advertisement, magazines, PC-programme about energy use and saving (Hein Nybroe, 2001; cited by Koeppel and Urge-Vorsatz, 2007).

${ }^{20}$ Utilities and telecommunication companies started developing "Smart energy boxes" allow the costumers to plan and manage directly the use of electric appliances, and manage decentralised generation facilities (Torriti et al., 2010).
} 


\subsubsection{Regulatory and control measures}

Regulatory and control measures are the most common in the residential sector. Normative measures include appliance standards ${ }^{21}$, buildings codes and EE obligations and quotas. Building codes can target the whole building, the envelope and/or major equipments, and are more difficult to apply to old buildings. Energy efficiency obligations and quotas oblige gas and electricity suppliers to achieve certain energy savings or demand peak reduction. Suppliers meet those targets by taking actions such as insulation, or improved heat pumps to save energy on the costumer's premises. In the US, twenty-two states have energy saving targets imposed on electricity utilities. Most of them are legally binding, and some of them are reinforced by large penalties if targets are not met (ACEEE, 2010).22

Informative measures include mandatory labels and certifications, originally used for appliances, but increasingly for whole buildings, as shown with the EPBD for instance (see Clarke et al., 2011, for a discussion of the EPBD). The update, tightening - as technology improves - and coverage expansion, in particular with respect to households electronics, are crucial (Fonseca et al., 2009). Standby consumption for instance should also be included, as it is estimated to account for 6 to $10 \%$ of residential electricity demand (EST, 2006).

Numerous studies report evidence of the strong impact from regulatory and control measures. Today, buildings codes vary widely across countries. Regulatory and control measures can reduce transaction costs to end-users, and provide high energy savings at low costs, sometimes at negative cost to society ${ }^{23}$. They can address many of the barriers outlined above, such as imperfect information, hidden/transaction costs, access to capital, and behavioural barriers such as lack of interest in energy issues. However, their success depends on several factors. The quality of enforcement is crucial. Appliance standards are easier to enforce than building codes, which in turn are easier to enforce in new buildings. ${ }^{24}$ The potential for rebound effect ${ }^{25}$ should be addressed, and a constant monitoring and regular updates to reflect technological progress are needed (see also Steinbucks, 2011 for more analysis).

\footnotetext{
${ }^{21}$ Products targeted by standards in the residential sector include appliances, ICT, lighting, heating and cooling equipments.

${ }^{22}$ Hence, in the state of Pennsylvania for instance, the Electricity Act 129 of 2008 requires distribution companies to meet specific levels of energy savings and demand reduction (1\% by 2011, and 3\% by 2013, compared to 20092010 sales). In case of failing to reach those targets, distribution companies can face a fine of at least $\$ 1$ million, and up to $\$ 20$ million (Act 129, 2008).

${ }^{23}$ Some costs estimates range from $-65 \$ / \mathrm{tCO}_{2}$ (US) to $-190 \$ / \mathrm{tCO} 0_{2}$ (EU) for appliances standards - hence a net benefit $-\dot{24}$

${ }^{24}$ This can be a major weakness as regards building codes, as the largest part of the building stock is composed by existing buildings in the UK.

${ }^{25}$ The rebound effect refers to the actual difference between improvements in the energy efficiency and reduction in energy consumption. The idea is that the rebound (or 'take-back') effect will lead to increases in consumption, due to the decrease in the per unit price of energy services. As a result, consumption of energy services should increase, partially offsetting the impact of the efficiency improvement. This basic mechanism is widely accepted, and numerous empirical studies suggest that these rebound effects are real and can be significant (Greening et al., 2000). However, the magnitude of this effect is disputed.
} 
In the US, some estimates suggest that current federal building standards should further account for $\$ 23$ billion savings by 2013 (CPUC, 2008). However, federal appliances standards are rarely updated and not very tight. By contrast, $30 \%$ of energy saved is attributed to product standards in California (IEA, 2007), and regular updates of buildings codes (every 3 years) might in part account for the great impact that building codes have had 26 . In the UK, despite the claim that building regulations led to an increase of around $70 \%$ of energy efficiency in buildings since 1990 (IEA, 2008), a more aggressive approach towards standards is needed (Hartley, 2006). Since September 2007, performance certificates are required for both new and existing buildings put into the market, as part of a Home Information Pack (CLG, 2010), and the government has announced its intention to extend their use (DECC, 2009). Key challenges remains in the UK: the low level of compliance - estimated to amount to only one third -; the lack of clarity due to a frequent and sporadic updates of regulations (in 2002, 2005, 2006, 2007); and finally, a lack of capacity to implement the regulations (IEA 2008b; Clarke, 2008; BRE, 2006). Data availability has also been a challenge, partly due to the division of responsibilities between DEFRA and BERR, which lasted until 2008. Also, the financial crisis as increased the ratio of energy efficiency investments to house values, reducing incentives for refurbishments (IEA, 2009a).

There is evidence that the impact of regulatory and control measures is enhanced when combined with specific measures addressing their weakness or side-effects. For instance, mandatory labelling can increase the benefit of appliance standards, which otherwise fail to incentivise innovation. For instance, standards have the benefits of imposing a minimum; but in principle do not provide any incentive to go beyond. Combinations with labelling can overcome this. In Japan, an innovative feature of the latest update of the Energy Conservation Law, in 2009, the pillar of Japanese energy policy, is the implementation of sectoral benchmarking targeting the efficiency performance of companies. Targets are set at the level of the top $10-20 \%$ best performance companies, with the publication of the names of the best companies (IEA, 2010). This "top-runner approach" was originally set in the 1990s to curb end-use appliances stagnating energy performance curves. Its coverage has been expanded several times, and includes appliances since 2005. This is an obligation on manufacturers of domestic appliances to produce products as efficient as the most efficient product in the product class by a specified date and a corresponding restriction on imported products. The regulator has a key role as it decides the categories of products and specific targets - yet after consultation with stakeholders (Nordqvist, 2007). In 2007, 21 homes appliances were covered, and in 2009, further products were considered for addition or revisions (routers, lighting, TV Sets, Computers and Magnetic Disk Units). The targets have been reached, with sometimes higher than expected improvements ${ }^{27}$ (IEA,

\footnotetext{
${ }^{26}$ The last update of the Title 24, Part 6, of the Building Energy Efficiency Standards, effective since 1 January 2010 includes a $15 \%$ increase in energy efficiency savings compared with the 2005 standards; and incorporate regulations targeting lighting and heating, ventilation and air-conditioning (HVAC), as well as a load control programme, the Programmable Communicating Thermostats, which enables the operators to reduce electricity load at peak times.

${ }^{27}$ Marked energy efficiency improvement (actual and projected efficiency): TV sets (25.7\% actual, $16.4 \%$ projected); Videotape recorders (73.6\% actual, $58.7 \%$ projected); Air Conditioners (67.8\% actual, $66.1 \%$ projected);
} 
2010). The strength of the measure lies in the targeting of the manufacturers, complemented with mandatory labelling which increases consumers awareness. Furthermore, the programme is clear and the standards are set with the active involvement of the manufacturers. Claims of the risk of gaming by manufacturers seem unfunded, as Japanese fame for high level technologies demonstrates, and the flexibility of the instrument, as targets are tightened if achieved earlier. Implementation of a top runner approach in the EU, at the national level could be much easier than at the European level, given the difference in purchasing capacity across countries. ${ }^{28}$ However, a strategy based on reputation might be more successful in a Japanese context, where social pressure is very strong.

Insulation requirements can also be enhanced by specific measures targeting low-income households, such as preferential loans for instance, or measures to incentivise their implementation. In Germany for instance, tenants are eligible for rebates on their rent if the landlord does not comply with some building codes. Some buildings labelling systems are combined with the issuance of mortgages or upgrades of homes, hence addressing financial barriers, while increasing awareness. For instance, in the US, the Home Energy Rating System (HERS) is used to guide energy efficient investments, to obtain energy efficiency mortgages, and to check for compliance with buildings standards. HERS is flexible, as despite being almost completely financed by federal funds, it is administered by the states that develop their standards. ${ }^{29}$

\subsubsection{Economic and market based instruments}

Economic and market based instruments essentially amounts to energy performance contracting (EPC) and energy services companies (ESCOs) support. ESCOs usually guarantee certain energy savings for a location over a specified period (see Kelly, 2011). The revenues are earned from the reduced energy costs achieved. Various barriers hamper ESCOs' expansion in the residential sector, in particular, the existence of split incentives, suspicion among customers, the difficulty for contractors to find financing sources or high transaction costs due to the small size of the projects ${ }^{30}$ - which, however, can be reduced with the bundling of similar projects.

Interest in EPC and the promotion of ESCOs is increasing recently, partly due to the fact that it avoids public spending or market intervention. In general, the development of ESCOs in the residential sector is promoted by any measure which triggers a market for energy efficiency. The presence of investors willing to lend to ESCOs and facilitating financial and market condition are crucial. The success of EPC varies from country to country, but the

Electric Refrigerators (55.2\% actual, 30.5\% projected); Electric Freezers (29.6\% actual, $22.9 \%$ projected) (IEA, 2010).

${ }^{28}$ Germany is the proponent of a similar approach at the European level.

${ }^{29}$ Amendment expanded the HERS to include energy efficiency ratings of smaller size homes and establish a systematic process for the rating for houses put in the market, including the evaluation of the options to increase EE (CEC website). Such measures have been found to be effective (IEA, 2008).

${ }^{30}$ For a complete list of barriers to EPC including other sectors, see (Koeppel and Urge-Vorsatz, 2007). 
case of US demonstrates its potential, with an estimated $3.2 \mathrm{MtCO}_{2}$ saved through EPC (Koeppel and Urge-Vorsatz, 2007).

\subsubsection{Financial/incentive-based measures}

Financial/incentive-based measures aims at correcting energy prices in order to reflect more accurately its costs, or address access to capital types of barriers, in particular the high up-front costs of energy efficiency investments. They can facilitate the introduction and commercialization of energy efficiency products. Energy taxes equalise compliance costs, and bring revenues for the government which can be invested in energy efficiency under the form of public benefits charges (PBC) (Koeppel and Urge-Vorsatz, 2007). Direct provision of financing includes preferential loans, grants and subsidies. Time-varying pricing refer to tariffs that vary according to the time electricity is used to reflect more accurately the costs of generation. It includes time of use (TOU), or real-time pricing (RTP) for instance. ${ }^{31}$ Other types of tariffs worth to be mentioned here are block tariffs, tariff that vary with the amount consumed. A common example of these is inclining block rates where a higher rate is charged per unit of consumption beyond a certain amount. Those have been applied for a long time in California to encourage conservation.

In the US, the four-year benefits charge, a small tax on electricity sales is used to fund DSM programs operated by utilities that include grants, loans and rebates (IEA, 2008). Taxes have several advantages. They can reinforce the impacts of other tools such as regulation and standards or being reinforced when combined with other measures. In Denmark, taxes complemented with subsidies, have resulted in 15\% reduction of $\mathrm{CO}_{2}$ between 1977 and 1991 (Koeppel and Urge-Vorsatz, 2007). In the UK, the impact of the Landlord's Energy Saving Allowance, introduced in 2004, as a VAT reduction of 5\% for grant-funded installation of energy-saving materials in priority homes and micro generation technologies is not clear yet. Some concerns remain as regards its clarity and lack of sustainability (IEA, 2008). Taxes address market barriers such as risk, or uncertainty related to energy efficiency investments, and importantly, they affect the whole building life, by contrast to other instruments. However, they can be difficult to implement politically and socially undesirable, by increasing energy prices and hence adversely affecting vulnerable households. ${ }^{32}$

Evaluation of the impact of taxes or time-varying pricing in the household sector is difficult, due to a lack of quantitative data. Factors such as the price elasticity of demand are important determinants of the impact whose estimated median values are low. ${ }^{33}$ For instance, the US federal tax has been found to be too small and short term to effect change in behaviour (IEA, 2008). The US Energy Tax Act of 1978, inducing a 15\% tax credit for

\footnotetext{
${ }^{31}$ TOU refers to tariffs that based on the time of the day where electricity is being consumption. TOU are fixed and set in advance, by contrast to RTP, a dynamic tariff which can vary up to every half-hour, being directly linked to the wholesale power markets.

${ }^{32}$ This concern is particularly important in the UK nowadays. See Waddams, 2011 and Meier and Jamasb, 2011, for a discussion of fuel poverty.

${ }^{33}$ Estimates of elasticities in the literature range from -0.15 to -0.39 in the short run and -0.09 to -0.579 in the long run.
} 
residential conservation and renewable energy measures, was not effective as the total amount was capped to $\$ 300$ and was not applicable to newest technologies (Koeppel and Urge-Vorsatz, 2007). Hence, taxes must be high enough and flexible enough to cover the best available technologies.

More than half of the measures targeting the residential sector identified in the MURE database $^{34}$ (MURE, 2010) are grants, preferential loans and rebates. Evidence suggests that they have a strong impact - with the majority of measures rated as having a high or medium impact. They are particularly useful as regards the introduction of new energy efficiency appliances/equipment and/or its targeting of access to capital in vulnerable households. However, such measures require financial resources, and are threatened by free-riding; hence they need to be carefully designed and their effectiveness increases with information/awareness raising campaigns.

\subsubsection{Voluntary action and public-private partnerships (PPP)}

Voluntary action and public-private partnerships (PPP) show some evidence on their impact. Voluntary labels and certification are commonly used for appliances. The US Energy Star labelling programme is often cited as a particularly successful example, with an estimated saving of around $833 \mathrm{MtCO}_{2}$ by 2010 (Gillingham et al., 2006), and a continuous increase in the number of sales of Energy Star qualified products since 2000, a saving estimated to 43 million Metric tons of GHG in 2008 and more than $\$ 19$ billion on utility bills US wide (Energy Star, 2008). This success was among others attributed to the combination of the measure with the obligation for public bodies to buy Energy Star appliances, and the governmental back-up needed to enhance trust among consumers (Banerjee and Solomon, 2003). It involves the interaction of the federal and state level, as it can incorporate statedeveloped initiatives. The programme is found to be more effective when ratings are used as benchmarks for other financial measures such as loans, grants and rebates (IEA, 2008).

The impact of voluntary agreements between companies and governmental bodies are more contested, as it can be used as a strategy by businesses to prevent stringent regulatory actions. On the positive side, as the company itself commit to a certain action, voluntary actions can be effective, more flexible and more cost-effective than regulatory measures. Moreover, when such actions are taken at the industry-wide level, it can drive competition for EE. However, the level of commitment can be lower than what would be socially desirable, although the threat of regulation can ensure some level of commitment.

PPP offer the best opportunities in terms of relevance flexibility, impact, clarity and sustainability (de T'Serclaes, 2007; UNEP, 2009), and enable the combination of the

\footnotetext{
${ }^{34}$ MURE II Database (MURE, 2010) provides information on EE policies implemented (including some impact assessments) in EU countries. It hence enables comparisons across countries. The MURE II Database is constructed in five, sections, including household sector and general cross-cutting measures.
} 
strength of private and public actors. In many cases, PPP have enhanced the impact of financial and incentive-based measures, such as in the case of the Germany with the KfW schemes. In other cases, PPP can take place in the very elaboration of framework policies, as in the case of the US 2008 National Action Plan for Energy Efficiency (NAPEE) illustrates, which included the collaboration of states, gas and electric utilities, utility regulators, and other partner organizations

\subsubsection{Information and capacity building measures}

Information and capacity building measures include utilities DSM/demand response programmes and education, public outreach and awareness campaigns. They are administered by a range of actors, including governmental agencies, regulators, local agencies, housing associations, and utilities, or else. They are soft measures, rarely impactful alone and often complement other tools, in particular as they help to minimize possible rebound effects and induce long-term behavioural change. They can nevertheless have significant impacts and address a range of informational and behavioural barriers particularly acute in the residential sector. In the US, non-governmental organisations ${ }^{35}$ play an important role in conveying information at state levels. In the UK, capacity building measures need to be enhanced, as seen with the low implementation of current building regulations (Clarke et al., 2008); appliances standards (Boardman, 2004) and quality of feedback (Pyrko and Darby, 2009).

Utilities DSM measures are flexible and foster market creation. In California, they were considered as the most effective measures (Eto et al., 1996). Such impact was made possible through a strategy that decouples the amount of electricity sold from revenues and hence realigns incentives between utilities and consumers in efficient resource allocation decisions. In particular, they can overcome market barriers such as the initial cost barriers (IEA 2008). Still today, the CPUC allocates $83 \%$ of its funds to programmes to utilities, further demonstrating the extent of huge involvement of utilities (IEA, 2008). However, competition brought by the restructuring of electricity markets can significantly reduce utilities' incentives to spend money on such programmes, despite the new opportunities opened up in new market structures.

The impact of awareness raising campaigns is difficult to disentangle from joint measures, and possible short and long term effects. Campaigns are particularly successful when the message is clear, carefully adapted to the targeted population, relevant to its needs, and create a social context which strengthens the impact (Weiss and Tschirhart, 1994). The Californian "Flex your power" campaign clearly stands out as a huge success: it induced a $8.9 \%$ reduction of peak demand and $6.7 \%$ energy consumption. The initiative involved partnerships with businesses, manufacturers, retailers, media organisations, and schools, targeting a large of the population through specific means. However, such programs can have adverse effects, such as in the UK, the free distribution of compact fluorescent lamps has discouraged the purchase of energy efficiency products, and undermined market

\footnotetext{
${ }^{35}$ They include the American Council for an Energy Efficient Economy (ACEEE), the Alliance to Save Energy
} (ASE) and the National Commission on Energy Policy. 
transformation. In the UK, the Energy Saving Trust centralizes all the information on available grants at all levels, and promotes partnerships for the supply of energy efficiency products, complementing other policies.

Detailed billing and smart meters provide consumers with detailed information about their consumption, either real time (smart-meters/real-time displays) or deferred (detailed/more frequent billing) ${ }^{36}$. The electricity savings induced with direct feedback range from 5-15\%37 (Darby, 2006). Factors that hamper the take-off of direct feedback tools can include the up-front costs of the device, imperfect information, specific regulatory barriers, and uncertainty. The ownership structure of the networks also complicates the roll-out. In the UK, the rolling-out of smart-meters in every home by 2020 has recently been decided (DECC, 2009). However, some crucial issues remain unresolved, especially as regard the treatment of consumption data, including the possibility for utilities to discriminate between consumers. Full results of trials, such as the UK Demand Reduction will be available in 2011 and might shed some light on those issues.

\footnotetext{
${ }^{36}$ For a discussion of smart meters technologies and economics, see Haney et al., 2011.

${ }^{37}$ The highest impacts were achieved with interactive displays unit, with smart-meters being more effective than innovative billings.
} 
Table 3 Assessment of individual policies

\begin{tabular}{|c|c|c|c|c|c|}
\hline Policy & I & C & Strengths & Weaknesses & Identified success factors \\
\hline $\begin{array}{l}\text { National EE } \\
\text { strategies and } \\
\text { action plans } \\
\text { (NEESAP) }\end{array}$ & & & $\begin{array}{l}\text { - facilitates integrative approach towards EE } \\
\text { and DSM }\end{array}$ & & \\
\hline \multicolumn{6}{|c|}{ Regulatory/ control measures } \\
\hline \multicolumn{6}{|c|}{ Normative } \\
\hline $\begin{array}{l}\text { Appliance } \\
\text { standards }\end{array}$ & $\mathrm{H}$ & $\mathrm{L}$ & $\begin{array}{l}\text { - reduces transaction costs } \\
\text { - easy administration } \\
\text { - can trigger market transformation } \\
\text { - eliminates worse practice by imposing a } \\
\text { minimum }\end{array}$ & $\begin{array}{l}\text { - no incentives for innovation } \\
\text { - rebound effect } \\
\text { - problem of enforcement }\end{array}$ & $\begin{array}{l}\text { - regular updates } \\
\text { - independent control } \\
\text { - clear communication } \\
\text { - quality testing } \\
\text { - "Top Runner Approach" } \\
\text { - enhanced effect when combined with information \& } \\
\text { capacity-building instruments } \\
\text { - should be maintained over time to phase out inefficient } \\
\text { technologies }\end{array}$ \\
\hline Building codes & $\begin{array}{l}\mathrm{M}- \\
\mathrm{H}\end{array}$ & M & $\begin{array}{l}\text { - reduces transaction costs } \\
\text { - imposes min. threshold } \\
\text { - can be very clear and effective }\end{array}$ & $\begin{array}{l}\text { - lack of compliance, partly due to lack of } \\
\text { standardization /market fragmentation } \\
\text { - rebound effect } \\
\text { - difficult to target existing building } \\
\text { - difficulty to respond rapidly to market } \\
\text { changes } \\
\text { - no incentive for over performance }\end{array}$ & $\begin{array}{l}\text { - flexibility, e.g. through regular updates (ex. UK EEC) } \\
\text { - need to be adapted to local context } \\
\text { - should reward over performance(ex. Japan GHLC) } \\
\text { - should be maintained over time for genuine market } \\
\text { change/phase out inefficient technologies } \\
\text { - need to be combined with capacity-building } \\
\text { measures/demonstration programmes } \\
\text { - enhanced effect when combined with mandatory (common) } \\
\text { M\&V (ex. California audits) }\end{array}$ \\
\hline EE obligations & $\mathrm{H}$ & $\mathrm{L}$ & $\begin{array}{l}\text { - relatively simple and flexible, as suppliers } \\
\text { choose the measure } \\
\text { - cheap administration } \\
\text { - no public expenditures } \\
\text { - can trigger market transformation } \\
\text { - can avoid regressive social impacts }\end{array}$ & $\begin{array}{l}\text { - can bring some increase in energy prices } \\
(1-2 \%) \\
\text { - can bring rebound effect }\end{array}$ & $\begin{array}{l}\text { - effects are maximised if government decides target and } \\
\text { discount } \\
\text { - regular updates } \\
\text { - need to be combined with mandatory M\&V and capacity- } \\
\text { building } \\
\text { - should be combined with financial incentives and } \\
\text { information measures }\end{array}$ \\
\hline \multicolumn{6}{|l|}{ Informative } \\
\hline $\begin{array}{l}\text { Mandatory labels } \\
\text { \& certificates }\end{array}$ & $\mathrm{H}$ & $\mathrm{L}$ & $\begin{array}{l}\text { - can achieve market transformation } \\
\text { - can be more effective than voluntary } \\
\text { labelling } \\
\text { - can be used for appliances and increasingly } \\
\text { whole buildings as well } \\
\text { - can be used as a marketing tool and basis } \\
\text { for reporting performance }\end{array}$ & $\begin{array}{l}\text { - evidence of case of lack of compliance } \\
\text { - rebound effect }\end{array}$ & $\begin{array}{l}\text { - stakeholder involvement in supervisory systems } \\
\text { - should be open-ended labelling, but with regular updates } \\
\text { - enhanced effect when combined with financial incentives } \\
\text { and M\&V (ex. Japan) }\end{array}$ \\
\hline
\end{tabular}




\begin{tabular}{|c|c|c|c|c|c|}
\hline $\begin{array}{l}\text { Mandatory } \\
\text { audits, M\&V }\end{array}$ & $\begin{array}{l}\mathrm{L}^{-} \\
\mathrm{H}\end{array}$ & $\begin{array}{l}\mathrm{L}- \\
\mathrm{M}\end{array}$ & & - difficult application to residential sector & $\begin{array}{l}\text { - stakeholder involvement in supervisory systems } \\
\text { - regular updates } \\
\text { - enhanced effect when combined with financial incentives }\end{array}$ \\
\hline \multicolumn{6}{|c|}{ Economic/market based instruments } \\
\hline EPC (by ESCOs) & $\mathrm{H}$ & $\mathrm{L}$ & $\begin{array}{l}\text { - cost-effective (repaid through savings, no } \\
\text { public spending) } \\
\text { - co-benefits: improved competitiveness } \\
\text { - no need of market intervention } \\
\text { - long term effects } \\
\text { - reduce risks, bounded rationality and } \\
\text { financial barriers } \\
\text { - reduce transaction costs by bundling small } \\
\text { size projects and filling the gap between } \\
\text { energy specialist and financier } \\
\text { - can be relevant, impactful and clear }\end{array}$ & $\begin{array}{l}\text { - often lack of equity capacity to endure } \\
\text { risk and uncertainty } \\
\text { - difficult to standardize small projects }\end{array}$ & $\begin{array}{l}\text { - need financial partners (e.g. private investors/ public } \\
\text { fund)/mature financial sector willing to lend for EE projects } \\
\text { - need unsubsidised and regionally uniform energy prices } \\
\text { - enhanced when combined with PPP with large institutional } \\
\text { investors/government support }\end{array}$ \\
\hline \multicolumn{6}{|c|}{ Financial / incentive-based measures } \\
\hline $\begin{array}{l}\text { Direct provision } \\
\text { of financing }\end{array}$ & $\begin{array}{l}\text { M. } \\
- \\
\mathrm{H}\end{array}$ & $\begin{array}{l}\mathrm{L}- \\
\mathrm{H}\end{array}$ & $\begin{array}{l}\text { - flexibility in the tools, but not on the targets } \\
\text { - rapid effect while can push market } \\
\text { transformation } \\
\text { - can effectively target access to initial cost } \\
\text { barriers } \\
\text { - can specifically address social issues -e.g. } \\
\text { fuel poverty by targeting vulnerable } \\
\text { households } \\
\text { - can have strong impacts (ex. DK) }\end{array}$ & $\begin{array}{l}\text { - no flexibility for the targets } \\
\text { - sometimes unclear } \\
\text { - difficult implementation on a wide-scale } \\
\text { - may create only short term "artificial" } \\
\text { demand, impact may last only until } \\
\text { programme ends } \\
\text { - lack of flexibility due to narrow targets in } \\
\text { some cases } \\
\text { - risk of free riders } \\
\text { - lack of awareness } \\
\text { - rebound effect } \\
\text { - administrative burden }\end{array}$ & $\begin{array}{l}\text { - need to be combined with information campaigns } \\
\text { - adapted to changing need of the markets } \\
\text { - should be limited in time and to specific segments } \\
\text { - should not be introduced once penetration rate of the } \\
\text { products is high } \\
\text { - need to be clear } \\
\text { - training and awareness campaign for sustainable impact } \\
\text { (ex. Denmark) } \\
\text { - better when involves PPP, which combines resources }\end{array}$ \\
\hline Fiscal measures & $\begin{array}{l}\text { L- } \\
\mathrm{H} \\
38\end{array}$ & $\begin{array}{l}\mathrm{L}^{-} \\
\mathrm{M}\end{array}$ & $\begin{array}{l}\text { - effective indirect financial tool } \\
\text { - can create demand } \\
\text { - flexible as market left to respond to the } \\
\text { demand } \\
\text { - can reinforce others instruments such as } \\
\text { regulations and standards } \\
\text { - affect the whole building life } \\
\text { - raise revenue } \\
\text { - tax exemption can stimulate introduction of } \\
\text { highly efficient equipment/appliances and } \\
\text { building materials }\end{array}$ & $\begin{array}{l}\text { - can encourage rebound effect if scope too } \\
\text { broad (e.g. France) } \\
\text { - often lack clarity } \\
\text { - free-rider problem } \\
\text {-difficult to address the vulnerable } \\
\text { household who still lack the extra cash } \\
\text { provision } \\
\text { - depends on price elasticity of demand }\end{array}$ & $\begin{array}{l}\text {-need to last to induce market transformation } \\
\text { - level and design - including the use of the revenues- of the } \\
\text { tax are crucial } \\
\text { - taxation is more effective when combined with other } \\
\text { measures }\end{array}$ \\
\hline
\end{tabular}

\footnotetext{
${ }^{38}$ Higher impact with tax exemptions.
} 


\begin{tabular}{|c|c|c|c|c|c|}
\hline charges & & & (through taxation & & $\begin{array}{l}\text { administration of the funds } \\
\text { - regular evaluation and adjustments } \\
\text { - clear and simple program design } \\
\text { - well designed use of the funds } \\
\text { - need training programmes (e.g. of the program } \\
\text { administrators) and M\&V measures }\end{array}$ \\
\hline $\begin{array}{l}\text { Utility-based } \\
\text { programs (load } \\
\text { control } \\
\text { programmes; } \\
\text { RTP, tariffs) }\end{array}$ & & & $\begin{array}{l}\text { - can effectively shave peak demand and shift } \\
\text { load }\end{array}$ & - can encourage rebound effect & - need awareness campaigns \\
\hline \multicolumn{6}{|c|}{ Voluntary agreements and public-private partnerships } \\
\hline PPP & $\begin{array}{l}\text { L- } \\
M\end{array}$ & M & $\begin{array}{l}\text { - faster decisions and implementation } \\
\text { - more flexible and cost-effective for the } \\
\text { companies }\end{array}$ & $\begin{array}{l}\text { - often lower outcomes than with } \\
\text { mandatory actions }\end{array}$ & $\begin{array}{l}\text { - can be effective when regulation are difficult to } \\
\text { enforce/combined with threat of regulation } \\
\text { - effective when industry-wide/all stakeholder are involved } \\
\text { - effective when clear quantitative targets and effective } \\
\text { monitoring }\end{array}$ \\
\hline $\begin{array}{l}\text { Voluntary } \\
\text { labelling \& } \\
\text { certificates }\end{array}$ & $\begin{array}{l}\mathrm{M}- \\
\mathrm{H}\end{array}$ & $\begin{array}{l}\mathrm{L}- \\
\mathrm{M}\end{array}$ & $\begin{array}{l}\text { - relevant contribution to other instruments } \\
\text { - can have a great impact and enhance } \\
\text { sustainability } \\
\text { - can affect upstream and downstream actors } \\
\text { - can have impact on consumers' behaviour } \\
\text { - send clear messages/information } \\
\text { - desirable when mandatory labels are not } \\
\text { possible/difficult to implement } \\
\text {-can be adapted to local conditions }\end{array}$ & $\begin{array}{l}\text { - not very flexible (no internal mechanism } \\
\text { to adapt to the evolution of the market and } \\
\text { response) } \\
\text { - weakened by lack of international } \\
\text { standards and may lack credibility } \\
\text { - only efficient products are labelled } \\
\text { - testing mechanisms may be of variable } \\
\text { quality }\end{array}$ & $\begin{array}{l}\text { - international labelling/testing standards can improve their } \\
\text { effectiveness } \\
\text { - label can be more efficient when combined with awareness } \\
\text { raising campaigns, fiscal incentives and/or regulations } \\
\text { - label should involve stakeholders and be backed by } \\
\text { government to be credible }\end{array}$ \\
\hline $\begin{array}{l}\text { Voluntary and } \\
\text { negotiated } \\
\text { agreements }\end{array}$ & $\begin{array}{l}\text { L- } \\
M\end{array}$ & $\mathrm{~L}$ & $\begin{array}{l}\text { - more flexible, and can be up to date than } \\
\text { regulation }\end{array}$ & $\begin{array}{l}\text { - can be used to strategically delay more } \\
\text { stringent measure by government }\end{array}$ & $\begin{array}{l}\text { - incentivise private companies } \\
\text { - threat of more stringent regulation }\end{array}$ \\
\hline \multicolumn{6}{|c|}{ Information and capacity-building } \\
\hline $\begin{array}{l}\text { Education and } \\
\text { public outreach } \\
\text { campaigns/awar } \\
\text { eness raising } \\
\text { campaigns }\end{array}$ & $\begin{array}{l}\text { L- } \\
\mathrm{M}\end{array}$ & $\begin{array}{l}\mathrm{M}- \\
\mathrm{H}\end{array}$ & $\begin{array}{l}\text { - strengthens long-term impact of most other } \\
\text { policy measures } \\
\text { - particularly needed as regards residential } \\
\text { sector } \\
\text { - sends clear messages }\end{array}$ & -can fail if not targeted to the needs & $\begin{array}{l}\text { - message must be clear, credible, and relevant to the target } \\
\text { audience } \\
\text { - must complement other measures }\end{array}$ \\
\hline $\begin{array}{l}\text { Training } \\
\text { programmes }\end{array}$ & $\mathrm{H}$ & & $\begin{array}{l}\text { - fill an important gap in terms of } \\
\text { competence, both upstream/downstream } \\
\text { - relevant contribution to other instruments } \\
\text { - can enhance sustainability } \\
\text { - can have impact on consumers' behaviour } \\
\text { - sends clear messages }\end{array}$ & & $\begin{array}{l}\text { - should be adapted to local conditions and target audience } \\
\text { - in complement to a wide range of other measures }\end{array}$ \\
\hline
\end{tabular}




\begin{tabular}{|c|c|c|c|c|c|}
\hline $\begin{array}{l}\text { Utility DSM/DR } \\
\text { programmes } \\
\text { (counselling and } \\
\text { general } \\
\text { information) }\end{array}$ & $\mathrm{H}$ & $\mathrm{L}$ & $\begin{array}{l}\text { - can be effective (usually lower in the } \\
\text { residential sector) and cost-effective } \\
\text { - can trigger }\end{array}$ & $\begin{array}{l}\text { - may be hampered by electricity market } \\
\text { restructuring }\end{array}$ & $\begin{array}{l}\text { - project must be carefully designed -adapted to local context } \\
\text { and market } \\
\text { - stakeholders must be involved } \\
\text { - objectives must be clear and some pilot programs first } \\
\text { - enhanced when triggered by regulatory incentives, and } \\
\text { combined with mandatory charges on electricity prices } \\
\text { - need complementary capacity-building/awareness raising } \\
\text { measures }\end{array}$ \\
\hline $\begin{array}{l}\text { Detailed billing } \\
\text { and disclosure } \\
\text { programs }\end{array}$ & $\mathrm{M}$ & M & - can induce long-term behavioural change & $\begin{array}{l}\text { - may be hampered by imperfect } \\
\text { information } \\
\text { - first-cost } \\
\text {-uncertainty about rate of return on } \\
\text { investment }\end{array}$ & $\begin{array}{l}\text { - combination with other measures } \\
\text { - regular assessments }\end{array}$ \\
\hline
\end{tabular}

Source: adapted from de T'Serclaes (2007); MURE (2010); UNEP (2009)

I: Impact; C: costs

H: high, M: medium, L: low 
In brief, regulatory and economic instruments have a high potential, but their outcome is ambiguous. Fiscal instruments can bring some savings if well designed, but the distributional impacts should be well understood. Subsidies are less cost-effective; and voluntary instruments' impact depends on the context and the accompanying measures. In general, all need to be accompanied by capacity building and educational measures. Besides, the timing of instrument is also of importance, as illustrated by Figure 4 which shows the combined effect of MEPS, rebates and labels.

Figure 4 Combined effects of MEPS, rebates and labels

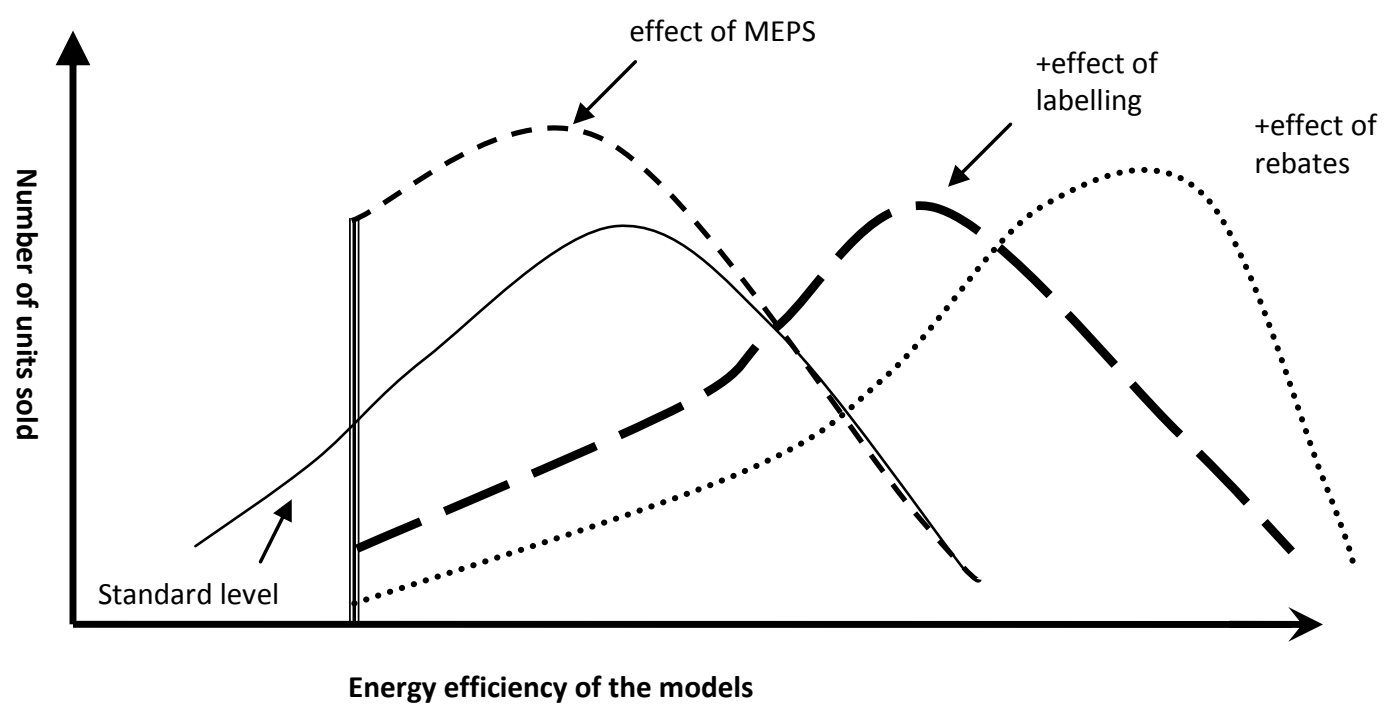

Source: UNEP (2007), CLASP (2005)

Finally, concerns over distribution of the costs and benefits further highlight the importance of design of the policies. Underlying the policy mix, the institutional framework must be designed as to help to address specific barriers. In the US, transaction costs are reduced, as the EPA centralizes all the information and guidelines related to the National Action Plan. By contrast, up until the creation of the Department of Energy and Climate Change (DECC) in 2008 which brought together energy and climate policies, the UK institutional organisation might have implied additional costs, complexity, risk of duplicates, and opacity in terms of the specific roles and responsibilities of Department for Business, Enterprise and Regulatory Reform (BERR) and the Department for Environment, Food and Rural Affairs, both involved in energy policy. 
Table 4 Estimated impacts of some implemented policies

\begin{tabular}{|c|c|c|}
\hline Policy & Estimated Impact & Costs \\
\hline \multicolumn{3}{|c|}{ Regulatory/ control measures } \\
\hline \multicolumn{3}{|c|}{ Normative } \\
\hline $\begin{array}{l}\text { Appliance } \\
\text { standards }\end{array}$ & $\begin{array}{l}\text { JP: } 31 \mathrm{M} \mathrm{tCO} \text { in } 2010 \\
\text { US: } 1990-97: 108 \mathrm{MtCO}_{2}, 65 \mathrm{MtCO}_{2} \text { in } 2000(2.5 \% \text { of electricity } \\
\text { use) }\end{array}$ & $\begin{array}{l}\text { JP: Top Runner Programme: actual and projected EE improvements: TV sets }(25.7 \% \\
\text { actual, } 16.4 \% \text { projected); Videotape recorders (73.6\% actual, } 58.7 \% \text { projected); Air } \\
\text { Conditioners (67.8\% actual, } 66.1 \% \text { projected);Electric Refrigerators (55.2\% actual, } \\
30.5 \% \text { projected); Electric Freezers ( } 29.6 \% \text { actual, } 22.9 \% \text { projected) } \\
\text { US: - } 65 \$ / \mathrm{tCO}_{2} \text { in } 2020\end{array}$ \\
\hline $\begin{array}{l}\text { Building codes } \\
\text { for both new \& } \\
\text { existing buildings }\end{array}$ & $\begin{array}{l}\text { UK: } 7 \% \text { less energy use housing, } 14 \% \text { with grants and } \\
\text { labelling, } \\
\text { UK: } 70 \% \text { increase in EE since } 1990 \\
\text { US: } 15-16 \% \text { of BAU }\left(79.6 \mathrm{MtCO}_{2} \text { in } 2000\right) \\
\text { EU: up to } 60 \% \text { for new buildings }\end{array}$ & $\begin{array}{l}\text { US: buildings and appliances standards: saved more than } \$ 56 \text { billions in energy bills } \\
\text { since 1978, estimated } \$ 23 \text { billions savings by } 2013 \text {. }\end{array}$ \\
\hline EE obligations & UK: $1.63 \%$ of total domestic $\mathrm{CO}_{2}\left(2.16 \mathrm{MtC}_{2} / \mathrm{yr}\right)$ & UK: $€ 17 / \mathrm{tCO}_{2}$ (DECC estimates) \\
\hline \multicolumn{3}{|l|}{ Informative } \\
\hline $\begin{array}{l}\text { Mandatory labels } \\
\& \quad \text { certification } \\
\text { programmes }\end{array}$ & DK: insignificant (Kjaerbye, 2009) & \\
\hline $\begin{array}{l}\text { Mandatory } \\
\text { audits, M\&V }\end{array}$ & $\begin{array}{l}\text { US weatherization program: } 22 \% \text { savings after audits, } 30 \% \\
\text { according to IEA) }\end{array}$ & US: 2.4 (benefit/cost ratio) \\
\hline \multicolumn{3}{|c|}{ Economic/Market based instruments } \\
\hline EPC & US: $20-40 \%$ of building energy saved, $3.2 \mathrm{MtCO}_{2} / \mathrm{yr}$ & $\begin{array}{l}\text { EU: Negative costs or less than } 22 \$ / \mathrm{tCO}_{2} \\
\text { US: cost benefits ratio in private sector: } 2.1\end{array}$ \\
\hline \multicolumn{3}{|c|}{ Financial and incentive-based measures } \\
\hline $\begin{array}{l}\text { Taxations/ tax } \\
\text { exemptions/tax } \\
\text { reductions }\end{array}$ & $\begin{array}{l}\text { Taxation: GE: household consumption reduced by } 0.9 \%, 1.5 \\
\mathrm{MtCO}_{2} \text { in } 2003\end{array}$ & US: benefit-cost ratio of tax exemptions for new homes: 1.6 \\
\hline $\begin{array}{l}\text { Subsidies and } \\
\text { grants }\end{array}$ & $\begin{array}{l}\text { UK: } 6.48 \mathrm{MtCO}_{2} \text { per year, } 100.8 \mathrm{MtCO}_{2} \text { in total, } 0.4 \% \text { in } \\
\text { average }\end{array}$ & $\begin{array}{l}\text { DK: }-20 \$ / \mathrm{tCO}_{2} \\
\mathrm{UK}: 29 \$ / \mathrm{tCO}_{2}\end{array}$ \\
\hline PBC & $\begin{array}{l}\text { US: } 0.1-0.8 \% \text { of total electricity sales saved per year, } 1.3 \\
\text { ktCO }{ }_{2} \text { in } 12 \text { states }\end{array}$ & US: form $-53 \$ / \mathrm{tCO}_{2}$ to $-17 \$ / \mathrm{tCO}_{2}$ \\
\hline $\begin{array}{l}\text { Utility } \\
\text { programs }\end{array}$ & $\begin{array}{l}\text { US: } 3.1 \% \text { in } 2000\left(36.7 \mathrm{MtCO}_{2}\right) \\
\text { DK: } 42 \% \text { of energy saving from } 2006 \text { to } 2008\left(0.8 \mathrm{MtCO}_{2}\right)\end{array}$ & $\begin{array}{l}\text { US: (average costs) }-35 \$ / \mathrm{tCO}_{2} \\
\text { EU: }-255 \$ / \mathrm{tCO}_{2} \\
\text { DK: }-209.3 \mathrm{~S} / \mathrm{tCO}_{2}\end{array}$ \\
\hline
\end{tabular}




\begin{tabular}{|c|c|c|}
\hline $\begin{array}{l}\text { voluntary } \\
\text { labelling } \quad \& \\
\text { certification }\end{array}$ & $\begin{array}{l}\text { US: Energy Star: } 43 \text { Millions Metric tons GHG since } 2000,13.2 \\
\mathrm{MtCO}_{2} \text { in } 2004,4 \% \text { reductions by } 2010,884 \mathrm{MtCO}_{2 \text { equ. In total }} \\
\text { by } 2012\end{array}$ & US: $-53 \$ / \mathrm{tCO}_{2}$ \\
\hline $\begin{array}{l}\text { Voluntary } \quad \& \\
\text { negotiated } \\
\text { agreements }\end{array}$ & $\begin{array}{l}\left.\text { US: } 5.6 \% \text { of total emissions ( } 66.45 \mathrm{MtCO}_{2 \text { equ }} \text { in } 2000\right) \\
\text { EU: } 50 \mathrm{ktCO}_{2}, 100 \mathrm{GWh} / \mathrm{yr}(300 \text { buildings) }\end{array}$ & \\
\hline \multicolumn{3}{|c|}{ Information and capacity-building } \\
\hline $\begin{array}{l}\text { Education, public } \\
\text { outreach/awaren } \\
\text { ess raising } \\
\text { campaign }\end{array}$ & $\begin{array}{l}\text { UK: around } 0.8 \% \mathrm{f} \text { total residential emissions in } 2009 \text { (10.4 } \\
\text { ktCO }{ }_{2} \text { per year) } \\
\text { California: } 6.7 \% \text { energy use reduction }\end{array}$ & UK: $8 \$ / \mathrm{tCO}_{2}$ for all Energy Trust Programmes \\
\hline $\begin{array}{l}\text { Detailed billing \& } \\
\text { disclosure } \\
\text { programmes }\end{array}$ & $\begin{array}{l}\text { Direct feedback: 5-15\%, up to 20\% (Darby, 2006) } \\
\text { UK: } 3 \%\end{array}$ & \\
\hline \multicolumn{3}{|c|}{ OVERALL CHANGE } \\
\hline & $\begin{array}{l}\text { UK: estimated } \mathrm{CO}_{2} \text { emission change from } 1980 \text { to } 2010 \text { : } \\
57.2 \% \text {; estimated future savings with current policies: } 2010 \\
\text { to } 2020: 2.13 \%\left(132,17 \mathrm{MtCO}_{2} \text { vs } 129.35\right) \\
\text { estimated impact of more ambitious but feasible policies: } \\
12.32 \%\end{array}$ & \\
\hline
\end{tabular}

UK: United-Kingdom, JP: Japan, GE: Germany, US: United States, DK: Denmark

Data may include savings from buildings in other sectors.

Source: Lee and Yik (2004); Geller et al. (2006); Koeppel and Urge-Vorsatz (2007); Energy Star programme website; DEFRA website 


\section{Policy packages and the importance of comprehensiveness}

\section{1 Integrated policy strategies}

There is now increasing awareness about the interactions between single policies and the recognition that energy efficiency targets require the coordination of a myriad of small actions across society. In terms of designing an optimal integrated strategy, two of the main aims are: to pursue multiple policy goals coherently; and to adopt mixes of policy instruments that are consistent and mutually supportive (Rayner and Howlett, 2009). An optimal integrated demand side strategy hence should seek to impact different parts of the market, and enhance the strengths of individual mechanisms while compensating for their weakness through the use of complementary measures (Gunningham and Sinclair, 1999; Jollands and Pasquier, 2008).

Hence, so-called "integrated policy strategies" have received much attention in various fields of late, materialized through the now numerous national energy efficiency strategies and actions plans (NEESAP). Barriers to energy efficiency and demand response are diffuse and as a result, policy mechanisms will rarely operate effectively in isolation (Sovacool, 2009). Many cross-country studies of demand-side policies come to the conclusion that comprehensive policy packages are a necessity if barriers are to be successfully overcome

\subsection{The UK versus international experience}

When compared to the policies set of Germany and Denmark, as listed in the MURE II database, the UK seems to have a balanced set of policies, with the participation of diverse actors. This contrasts with, for instance Germany's more centralised implementation (Figure 5). Similarly, the range of policies is wide. However, there is still large potential and scope for improvement. So what explains the still poor performance of energy use in households in the UK as compared to, for instance, Denmark or Germany? We suggest that the UK large untapped potential remains particularly large because of a lack of an underlying holistic approach view in energy policy, which, by extension, permeates all dimensions of DSM. 
Figure 5 Actors involved in DSM policies in the UK, Denmark, and Germany

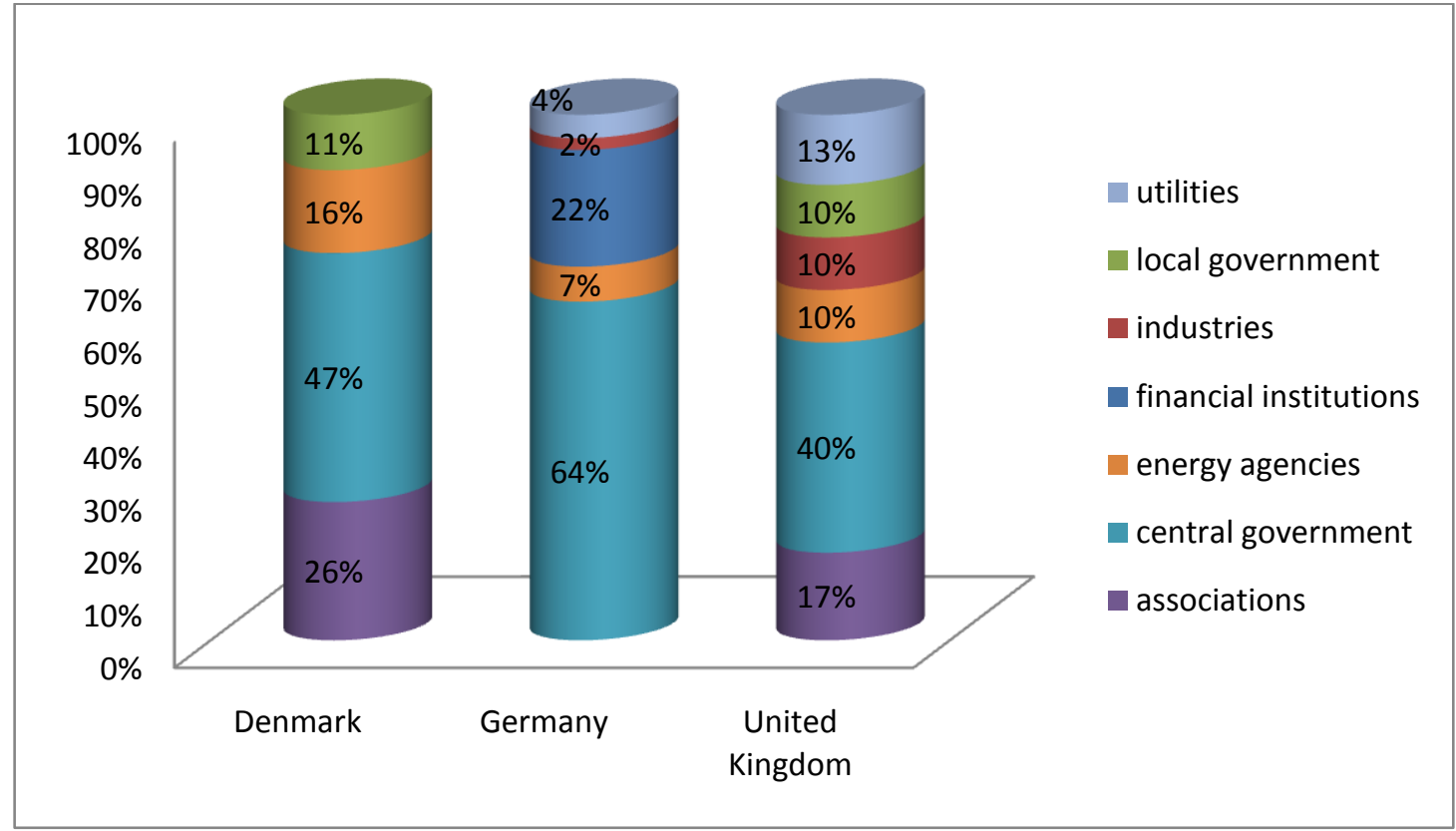

Source: (MURE, 2010)

Figure 6 Type of measures implemented in the UK, Denmark, Germany

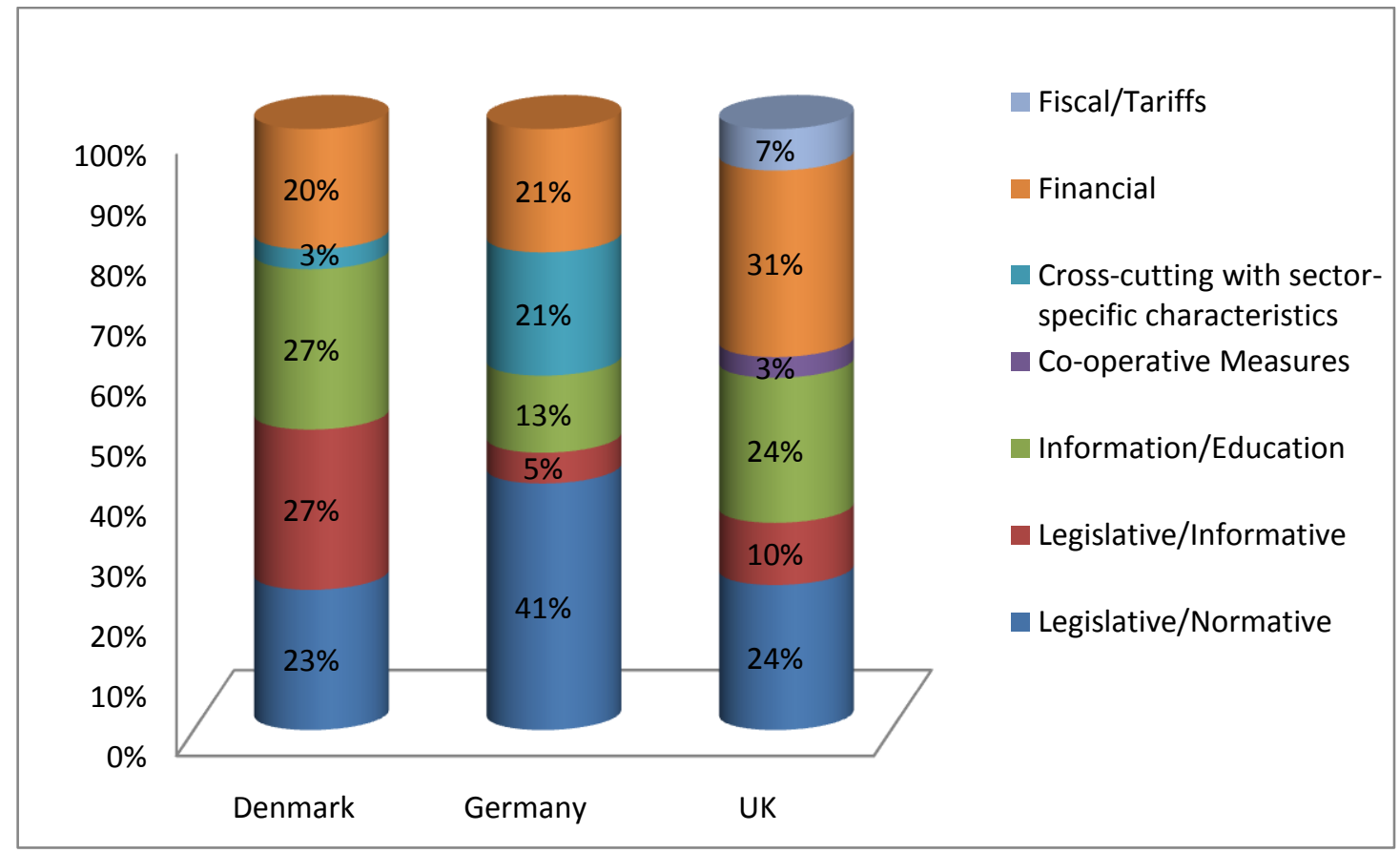

Source: (MURE, 2010)

Strategic view would manifest in an integrative policy package, implying coherence, coordination and long term view. In Denmark for instance, energy savings in buildings has been a major focus of energy policy since 1975. Environmental preservation, awareness and concern is embedded in the Danish culture. Primary supply of energy for heating has decreased by more than $20 \%$ despite a $34 \%$ of increase in heating space (IEA, 2006). Buildings regulations to 
curb heating needs have been tightened since 1977, offering predictability to construction companies. Enforcement of those codes, and labelling strictly reflecting them demonstrate an underlying coherent view, complemented by a strong policy with respect of CHP and district heating.

In the US, the 2008 National Action Plan for Energy Efficiency (NAPEE) calls for a sustainable national commitment in all sectors. Such goals are taken back in state level reports: the 2009 Integrated Energy Policy Report (IEPR) and the 2008 California Long-term Energy Efficiency Strategic Plan (EESP). Both announce the ambitious targets of making all new residential constructions "Zero Net Energy" ${ }^{39}$ by 2020 (CPUC, 2008; CEC, 2009). The case of California illustrates the necessity of involvement of all three levels federal, regional and local. The federal level, important as regard capacity-building, as it provides important funding; provides the guiding strategies and a toolkit for state and local authorities reducing state level costs to enact policies. Buildings and appliances standards, necessary at the federal level, benefit from some flexibility at the state level, as states have better information and can better target the standards to the characteristics. Regional associations, such as WGA can add clarity and harmonize targets. All this plead for simultaneous initiatives at all three levels.

The Californian policies demonstrate several strengths in terms of relevance, flexibility, clarity, and sustainability. Also, coherence is visible, as some policies are coupled together and hence, their impact strengthened. The Energy Star labels are used as criteria for loans and grants attribution. Building regulation updates go hand in hand with increased usage of energy efficient appliances (IEA, 2008). Finally, it also shows the necessity of public awareness, an essential element in the strategy. Future challenges include the need to better gather data in order to improve future energy demand forecast; assess the quantitative impacts in post-evaluation studies, while trying to distinguish between the different factors influencing the outcome (Vine et al., 2006).

Although the Japanese policies show some weaknesses, such as the need to target more rural households - responsible for $52.5 \%$ of the total residential building sector - and to extend the scope of some measures (Ashina and Nakata, 2008), they reveal an underlying integrative conceptual approach, where policies are combined and target multiple barriers. Innovative features include, for instance, the use of regulations as benchmarks for voluntary labels and the provision of subsidies. The Top Runner standard for instance has been used as a reference point for voluntary labels. Specific measures such as labels or grants simultaneously address several barriers at the same time - access to capital or behavioural barriers-, while targeting a wide range of actors at different levels from consumers to manufacturers and local governments - through effective partnerships.

\footnotetext{
${ }^{39}$ Zero Net Energy buildings would contain generation technologies and be connected to the grid so as to export energy when there is a surplus and import when not enough is produced (CPUC, 2008).
} 
On the contrary, UK policies seem heavily shaped by short term politics and a particular conceptual rationale. The UK government recognizes the need for combination of policies and enhanced coordination (DTI, 2007; IEA, 2008; NAO, 2008). However, the wide range of measures adopted in general, and elaborated in the EEAP 2007 for instance bear the risk of resource dispersion as well as difficulty of evaluation and comparison. Small incremental steps still overtake a more comprehensive and integrative approach which would have the advantage of enhancing market transformation. Also, clearer and longer term targets strengthen the latter.

For instance, a confusing number of different measures specifically target fuel poverty - the Warm Front, Reduced VAT for energy-saving materials, Decent Homes, Warm Zones, the Low carbon Buildings Programmes -. Differences between them seem rather small. They could achieve more with increased flexibility and a continuous funding (Pyrko and Darby, 2009). Besides, and perhaps more importantly, constant incremental updates and changes in framework policies, evidenced through serial publications of "long-term" energy white papers and plans - 1998, 2003, 2006, 2007, 2008, 2009 - affect credibility and unhinge a sector traditionally known for its long term investments, and need for certainty and predictability. Frequent changes of Secretaries of State responsible for energy which stayed on average 15 months are also detrimental for a long-term perspective.

Furthermore, our discussion has demonstrated the need for data gathering and ex-post evaluations. The Danish Energy Saving Trust, an independent body itself, is subject to frequent reviews by an independent body. UK measures unveil a lack of focus and understanding of the actual impact of policies, with very few evaluations and post studies. Modelling of building performance, compliance to buildings regulations and ex-post evaluation studies would facilitate the monitoring of the impacts and progress of the measure. Dedicated reviews need to be put in place.

However, no size fits all in term of approach towards DSM. Japan provides a very good illustration of a "horizontally driven" policy package, targeting a wide range of actors. The measures are multidimensional, entering in several of type of categories identified and by extension, addressing multiple barriers. Californian policies, by contrast, are vertically articulated, with a multistage implementation: federal, regional and state, combining utilities' participation.

\section{Conclusion}

In its review of programmes targeting financial barriers (de T'Serclaes, 2007) finds that the challenges to energy efficiency rather lie on a more carefully designed policy packages than on an increase in financial resources. A successful strategy is the combination of "sticks" (regulations) with "carrots" (incentives) and "tambourines" (awareness raising campaign) (Warren, 2007, cited by Koeppel and Urge-Vorsatz, 2007). Our review of policies has provided some evidence on this. We have shown that an integrated demand side strategy is 
based on the recognition that no singly policy alone can overcome the barriers to energy efficiency, which are diverse and spread out over a wide range of actors and sectors. Policies may address several barriers at the same time and treating them as complementary strengthens their impact (Lee and Yik, 2004; Sovacool, 2009).

This requires an "integrated policy strategy", i.e. a holistic underlying approach. We suggested that packages of policies reveal different cultural and conceptual approaches, as well as methodologies and that policy making might benefit from departing from a focus on the strengths and weaknesses of isolated instruments towards a more comprehensive analysis accounting for their interactions. This also opens new avenues for research, as in dynamic modelling for instance; and the need of creating a market for energy efficiency, still very rare. In the UK for instance, the reliance on marginal abatement cost curves as aid for policymaking might explain the existing lack of coherence. On the contrary, Denmark's culture for environmental preservation which goes far beyond the energy sector could well facilitate an integrative approach. The Japanese example reveals an explicit account and exploitation of policy interactions.

"Success" factors of a well-designed energy efficiency strategy have been provided, such as the existence of clear objectives and mandates; the participation of stakeholders; the ability to combine flexibility and sustainability; and the ability to adapt and integrate adjacent policies (Harmelink et al., 2008). Flexibility is required as policies interact with each other, and their impact evolves over time. Sustainability creates certainty and can be fostered through the integration into market transformation strategies (Sovacool, 2009). The most successful packages are clear, effective and sustainable while remaining flexible. The importance of post-evaluation studies and benchmarking has also been highlighted repeatedly (Lee and Yik, 2004; IEA, 2009a). As regards the specific mix of policies, particularly effective combinations involve both private and public actors, e.g. through PPP. Effective DSM measures difficultly take off by private actors, and government action is often needed to encourage action and investments by private actors. Hence, political will is required, in order to reduce uncertainty. In general, policy-makers show a move towards a holistic approach (Lee and Yik, 2004). In the US, Denmark and Japan, integrated packages of DSM come throughout each of the more general energy efficiency measure. As such, they do not duplicate energy efficiency measures in the residential sector, but rather augment and strengthen them, as illustrated in the case of California (CPUC, 2008).

Those countries can provide useful lessons for the UK. UK policies show a move toward packages of integrated policies, yet there is still scope for improvement, especially in terms of $M \& V$, clarification and coordination. However, as we have seen, given the poor quality of building, capacity-building measures should be strengthened, refurbishments promoted, and building regulations better enforced. The plethora of existing tariffs, grants programmes, offers a rather confusing impression and may miss its targets. In general, weaknesses must be identified and targeted. Some policies need to be complemented through 
awareness measures, such shown by the SAP ratings for instance. Product policy should precede higher prices; taxation should be a mean to enable low-income families buying more energy efficient products. As regard behaviour, the ideal condition would be a mix of consumer "pull" and manufacturers "push" measures (Boardman, 2007). This focus on single policies alone might have been the result of reliance on "Marginal Abatement Cost Curves" approach, which indicates which measures are most cost effective on a one-by-one basis. However, such disaggregation conceals the interactions between measures, which can imply a very different strategy.

On the institutional side, the recent creation of the Department for Energy and Climate Change (DECC) might reduce hidden costs and facilitate coordination. Its role and functions could make DECC the leading department in the development of a holistic strategy taking explicitly into account dynamic interdependencies and based on empirical evidence and regulator's independent advice. However, the particular administration and implementation of specific policies should be carried by the most appropriate governmental and non-governmental bodies exploiting their capacities strategically: the Energy Saving Trust local energy saving centres' experience and knowledge on local conditions as well as privileged relationship with citizens; the Department for Communities and Local Government's established collaboration with local authorities; and Ofgem's advisory capacities and extended knowledge of the energy supply market. The latter could promote PPPs' opportunities and ensure the independent measurement and evaluation of some policies.

\section{References}

Act 129 (2008). Available at

http://www.puc.state.pa.us/electric/pdf/Act129/HB2200-Act129 Bill.pdf, last accessed 2 August 2010.

ACEEE (2010). State Energy Efficiency Resource Standards, (EERS) Activity. Available at

http://www.aceee.org/energy/state/State\%20EERS\%20Summary\%20Jan\%202 010.pdf, last accessed 2 August 2010

Alam, M., J. Sathaye and D. Barnes (1998). Urban household energy use in India: efficiency and policy implications. Energy Policy 26(11): 885-891.

Ang, B. W. (2006). Monitoring changes in economy-wide energy efficiency: From energy-GDP ratio to composite efficiency index. Energy Policy 34(5): 574-582.

Ashina, S. and T. Nakata (2008). Energy-efficiency strategy for CO2 emissions in a residential sector in Japan. Applied Energy 85(2-3): 101-114. 
Banerjee, A. and B. D. Solomon (2003). Eco-labeling for energy efficiency and sustainability: a meta-evaluation of US programs. Energy Policy 31(2): 109-123. Bilton, M., C. Ramsay, M. Leach, H. Devine-Wright, P. Devine-Wright and D. Kirschen (2008). Domestic electricity consumption and demand-side participation: opportunities and challenges for the UK power system. Delivering a Low-Carbon Electricity System: Technologies, Economics and Policy. M. Grubb, T. Jamasb and M. Pollitt. Cambridge, UK, Cambridge University Press: 207-228.

Blumstein, C., C. Goldman and G. Barbose (2005). Who should administer energyefficiency programs? Energy Policy 33(8): 1053-1067.

Boardman, B. (2005). Domestic Energy Fact File. ECEEE Summer Study - What works and who delivers? .

Boardman, B. (2007). Home Truths: A Low-Carbon Strategy to reduce UK Housing Emissions by $80 \%$ by 2050. Oxford, UK: ECI.

BRE (2008). Domestic Energy Fact File 2008. UK: BRE Housing.

Brophy Haney, A., T. Jamasb,. and M. Pollitt (2011). Smart metering: Technology Economics and International Experience. The Future of Electricity Demand: Customers, Citizens and Loads. T. Jamasb and M. Pollitt. Cambridge, UK, Cambridge University Press: forthcoming.

Brown, M. A. (2001). Market failures and barriers as a basis for clean energy policies. Energy Policy 29(14): 1197-1207.

CEC (2009). 2009 Integrated Energy Policy Report, Final Commission report, December 2009. California, US: California Energy Commission.

Clarke, J. A., C. M. Johnstone, N. J. Kelly, P. A. Strachan and P. Tuohy (2008). The role of built environment energy efficiency in a sustainable UK energy economy. Energy Policy 36(12): 4605-4609.

Clarke, J.A., J. Hong, C.M. Johnstone,, J.M. Kim, and P. Tuohy (2011).The potential impact of policy and legislation on the energy demands of UK buildings and implications for the electrical network. The Future of Electricity Demand: Customers, Citizens and Loads. T. Jamasb and M. Pollitt. Cambridge, UK, Cambridge University Press: forthcoming. 
CLG. (2010). Communities and Local Government website. Retrieved 2 August 2010, from http://www.communities.gov.uk/corporate/.

CLASP (2005), A Standards \& Labeling Guidebook for Appliances, Equipment, and Lighting (2nd Edition) - English Version, The Collaborative Labeling and Appliance Standards Program (CLASP), Washington, US, available at http://www.clasponline.org/clasp.online.resource.php?sbo=289, last accessed 28 August 2010.

CPUC (2008). California Long Term Energy Efficiency Strategic Plan. California, US: California Public Utilities Commission.

CRA (2005). Primer on demand-side management. Oakland, CA: Prepared for the World Bank by Charles River Associates.

Darby, S. (2006). The effectiveness of feedback on energy consumption. Oxford, UK: Environmental Change Institute, University of Oxford

de T'Serclaes, P. (2007). Financing energy efficient homes: Existing policy responses to financial barriers. Paris, France: International Energy Agency.

DECC (2009). The UK Low Carbon Transition Plan: National Strategy for Climate and Energy. London, UK: Department of Energy and Climate Change.

DECC. (2010). Energy consumption in the United Kingdom. Retrieved 16 August 2010, 2010, from

http://www.decc.gov.uk/en/content/cms/statistics/publications/ecuk/ecuk.as $\underline{\mathrm{px}}$.

Deringer, J., M. Iyer and Y. J. Yu Joe Huang (2004). Transferred just on paper? Why doesn't the reality of Transferring/Adapting Energy Efficiency Codes and Standards come close to the potential? ACEEE Summer Study on Energy Efficiency in Buildings, Pacific Grove, California, US, ACEEE.

DTI (2007). Meeting the Energy Challenge: A White Paper on Energy. London, UK: Department for Trade and Industry.

EERE. (2010). US Department of Energy, Energy Efficiency and Renewable Energy. Retrieved 27 July 2010, from 
http://www1.eere.energy.gov/ba/pba/intensityindicators/trend definitions.ht $\underline{\mathrm{ml}}$.

Eldridge, M., M. Neubauer, D. York, S. Vaidyanathan, A. Chittum and S. Nadel (2008). The 2008 State Energy Efficiency Scorecard, Washington, DC, American Council for an Energy-Efficient Economy (ACEEE).

Energy Star (2008). 2008 Annual Report. Energy Star.

EST (2006). The rise of the machine: a review of energy using products in the home from the 1970s to today. London, UK: Energy Saving Trust.

Eto, J., R. Prahl and J. Schlegel (1996). A Scoping Study on Energy-Efficiency Market Transformation by California Utility DSM Programs. LBNL 39058.

Fonseca, P., A. de Almeida, N. Feilberg, G. Markogiannakis and C. Kofod (2009). Characterization of the household electricity consumption in the EU, potential energy savings and specific policy recommendations. ECEEE 2009 Summer Study, France.

Geller, H., P. Harrington, A. H. Rosenfeld, S. Tanishima and F. Unander (2006). Policies for increasing energy efficiency: Thirty years of experience in OECD countries. Energy Policy 34(5): 556-573.

Gillingham, K., R. Newell and K. Palmer (2006). Energy Efficiency Policies: A Retrospective Examination. Annual Review of Environment and Resources 31(1): 161-192.

Greening, L. A., D. L. Greene and C. Difiglio (2000). Energy efficiency and consumption - the rebound effect - a survey. Energy Policy 28(6-7): 389-401.

Gunningham, N. and D. Sinclair (1999). Regulatory pluralism: Designing Policy Mixes for Environmental Protection. Law and Policy 41(1): 49-74.

Harmelink, M., L. Nilsson and R. Harmsen (2008). Theory-based policy evaluation of 20 energy efficiency instruments. Energy Efficiency 1(2): 131-148.

Hartley, N. (2006). The 2006 Review of Energy Policy: the Main Issues. Political Quarterly 77(1): 117-123. 
IEA (2005). Evaluating energy efficiency policy measures and DSM programmes: Volume II country reports and case examples used for the evaluation guide book. Sittard, the Netherlands: IEA.

IEA (2006). Denmark 2006 Review. Paris, France: International Energy Agency.

IEA (2007). Energy use in the new millenium: Trends in IEA countries. Paris, France: International Energy Agency.

IEA (2008). Promoting Energy Efficiency: Case studies in the residential sector. Paris, France, International Energy Agency.

IEA (2009a). Financial crisis and energy efficiency. Paris, France: OECD/IEA.

IEA (2009b). Implementing Energy Efficiency Policies: are IEA member countries on track? Paris, France: Internationl Energy Agency.

IEA (2009c). Progress with Implementing Energy Efficiency Policies in the G8. Paris, France: International Energy Agency.

IEA. (2010). Energy Efficiency Policies and Measures Database. Retrieved 3 February 2010, 2009-2010, from http://www.iea.org/textbase/pm/?mode=pm.

Jaffe, A. B., R. Newell and S. R. N. . (1999). Energy-efficient technologies and climate change policies: Issues and evidence. Washington, DC: Resources for the Future.

Jaffe, A. B. and R. N. Stavins (1994). The energy-efficiency gap What does it mean? Energy Policy 22(10): 804-810.

Jamasb T,. and H. Meier (2011). Energy Spending and Vulnerable Households. The Future of Electricity Demand: Customers, Citizens and Loads. T. Jamasb and M. Pollitt. Cambridge, UK, Cambridge University Press: forthcoming.

Jollands, N. and S. Pasquier (2008). Innovations in National Energy Efficiency Strategies and Action Plans. Workshop on Innovations in National Energy Efficiency Strategies and Action Plans. International Energy Agency, Paris, France.

Kelly S., (2011). The Local Dimension of Energy. The Future of Electricity Demand: Customers, Citizens and Loads. T. Jamasb and M. Pollitt. Cambridge, UK, Cambridge University Press: forthcoming. 
Koeppel, S. and D. Urge-Vorsatz (2007). Assessment of Policy Instruments for Reducing Greenhouse Gas Emissions from Buildings. Budapest, Hungary: Central European University.

Lee, W. L. and F. W. H. Yik (2004). Regulatory and voluntary approaches for enhancing building energy efficiency. Progress in Energy and Combustion Science 30(5): 477-499.

McKinsey (2007). Curbing global energy demand growth: The energy productivity opportunity. San Francisco, CA: McKinsey Global Institute.

McKinsey (2008). The case for investing in energy productivity. San Francisco, USA: McKinsey Global Institute.

McKinsey (2009). Averting the next energy crisis: The demand challenge. San Francisco; Houston: McKinsey \& Company and McKinsey Global Institute.

MURE (2008). Energy Efficiency Profile: UK. MURE.

MURE (2009). Energy Efficiency Policies and Measures in the UK 2009.

MURE. (2010). Mesures d'Utilisation Rationnelle de l'Energie. Retrieved 3 February 2010, 2010, from http://www.isisrome.com/mure/.

NAO (2008). Programmes to reduce household energy consumption. London, UK: National Audit Office.

Nordqvist, J. (2007). The Top Runner policy concept: Pass it down? ECEEE 2007 SUMMER STUDY: SAVING ENERGY - JUST DO IT!, La Colle sur Loup, France.

Pyrko, J. and S. Darby (2009). Conditions of behavrioual changes towards efficient energy use - a comparative study between Sweden and the United Kingdom. ECEEE 2009 Summer Study: Act! Innovate! Deliver! Reducing Energy Demand Sustainably, Côte d'Azur, France, ECEEE.

Ramesohl, S. and C. Dudda (2001). Barriers to energy service contracting and the role of standardised measurement and verification schemes as a tool to remove them European Council For An Energy Efficient Economy 2001 Summer Study proceedings. 
Rayner, J. and M. Howlett (2009). Introduction: Understanding integrated policy strategies and their evolution. Policy and Society 28(2): 99-109.

Silva, V., Stanojevic, V., Aunedi, M., Pudjianto, D. and G. Strbac (2011). Smart domestic appliances as enabling technology for demand side integration: modelling, value and drivers. The Future of Electricity Demand: Customers, Citizens and Loads. T. Jamasb and M. Pollitt. Cambridge, UK, Cambridge University Press: forthcoming.

Sorrell, S. (2004). Understanding Barriers to Energy Efficiency. The Economics of Energy Efficiency. S. Sorrell, E. O'Malley, J. Schleich and S. Scott. Cheltenham, UK Edward Elgar: 25-95.

Sovacool, B. K. (2009). The importance of comprehensiveness in renewable electricity and energy-efficiency policy. Energy Policy 37(4): 1529 -1541.

Taylor, P., O. L. d'Ortigue, M. Francoeur and N. Trudeau (In Press). Final energy use in IEA countries: The role of energy efficiency. Energy Policy In Press, Corrected Proof.

Torriti, J., M. G. Hassan and M. Leach (2010). Demand response experience in Europe: Policies, programmes and implementation. Energy 35(4): 1575-1583.

Torriti, J., M. Leach and P. Devine-Wright (2011). Demand side participation: price constraints, technical limits and behavioural risk. The Future of Electricity Demand: Customers, Citizens and Loads. T. Jamasb and M. Pollitt. Cambridge, UK, Cambridge University Press: forthcoming.

Uihlein, A. and P. Eder (2009). Towards additional policies to improve the environmental performance of buildings. Luxembourg: European Communities and Institute for Prospective Technological Studies.

Unander, F., I. Ettestøl, M. Ting and L. Schipper (2004). Residential energy use: an international perspective on long-term trends in Denmark, Norway and Sweden. Energy Policy 32(12): 1395-1404.

UNEP (2009). Buildings and Climate Change. Paris: United National Environment Programme Sustainable Buildings \& Climate Initiative (UNEP-SBCI). 
Utley, J. I. and L. D. Shorrock (2008). Domestic Energy Fact File 2008. UK: BRE Housing.

Varone, F. and B. Aebischer (2001). Energy efficiency: The challenges of policy design. Energy Policy 29(8): 615-629.

Vine, E., J. Hamrin, N. Eyre, D. Crossley, M. Maloney and G. Watt (2003). Public policy analysis of energy efficiency and load management in changing electricity businesses. Energy Policy 31(5): 405-430.

Vine, E., C. H. Rhee and K. D. Lee (2006). Measurement and evaluation of energy efficiency programs: California and South Korea. Energy 31(6-7): 1100-1113.

WEC (2008). Energy Efficiency Policies around the World: Review and Evaluation. London, UK: World Energy Council. 